\title{
Along-Stream Evolution of Gulf Stream Volume Transport
}

\author{
JOLEEN HEIDERICH \\ MIT-WHOI Joint Program in Oceanography/Applied Ocean Science and Engineering, Woods Hole, Massachusetts \\ ROBERT E. TODD \\ Woods Hole Oceanographic Institution, Woods Hole, Massachusetts
}

(Manuscript received 6 December 2019, in final form 16 May 2020)

\begin{abstract}
The Gulf Stream affects global climate by transporting water and heat poleward. The current's volume transport increases markedly along the U.S. East Coast. An extensive observing program using autonomous underwater gliders provides finescale, subsurface observations of hydrography and velocity spanning more than $15^{\circ}$ of latitude along the path of the Gulf Stream, thereby filling a $1500-\mathrm{km}$ long gap between long-term transport measurements in the Florida Strait and downstream of Cape Hatteras. Here, the glider-based observations are combined with shipboard measurements along Line W near $68^{\circ} \mathrm{W}$ to provide a detailed picture of the along-stream transport increase. To account for the influences of Gulf Stream curvature and adjacent circulation (e.g., corotating eddies) on transport estimates, upper- and lower-bound transports are constructed for each cross-Gulf Stream transect. The upper-bound estimate for time-averaged volume transport above $1000 \mathrm{~m}$ is $32.9 \pm 1.2 \mathrm{~Sv}(1 \mathrm{~Sv} \equiv$ $10^{6} \mathrm{~m}^{3} \mathrm{~s}^{-1}$ ) in the Florida Strait, $57.3 \pm 1.9 \mathrm{~Sv}$ at Cape Hatteras, and $75.6 \pm 4.7 \mathrm{~Sv}$ at Line W. Corresponding lower-bound estimates are $32.3 \pm 1.1 \mathrm{~Sv}$ in the Florida Strait, $54.5 \pm 1.7 \mathrm{~Sv}$ at Cape Hatteras, and $69.9 \pm 4.2 \mathrm{~Sv}$ at Line W. Using the temperature and salinity observations from gliders and Line W, waters are divided into seven classes to investigate the properties of waters that are transported by and entrained into the Gulf Stream. Most of the increase in overall Gulf Stream volume transport above $1000 \mathrm{~m}$ stems from the entrainment of subthermocline waters, including upper Labrador Sea Water and Eighteen Degree Water.
\end{abstract}

\section{Introduction}

The Gulf Stream is the subtropical western boundary current of the North Atlantic and thus redistributes heat, salt, and carbon in the global climate system (Wunsch 2005; Schmittner and Galbraith 2008; Kwon et al. 2010). As a principal component of the upper limb of the Atlantic meridional overturning circulation, the Gulf Stream contributes significantly to poleward heat and volume transport (Cunningham et al. 2007). This strong, narrow current carries warm, saline waters from the tropics to higher latitudes, thereby balancing equatorward transport in the ocean interior, including both wind-driven equatorward transport in the upper ocean (Sverdrup 1947; Stommel 1948; Munk 1950) and equatorward thermohaline flow at depth (Stommel and Arons 1959; Wunsch and Roemmich 1985).

\footnotetext{
Corresponding author: Joleen Heiderich, joleenh@mit.edu
}

The Gulf Stream flows along the U.S. East Coast before separating from the continental margin near Cape Hatteras, North Carolina, encountering different dynamical regimes on its way north. The current transitions from a strong, relatively straight jet in the confined channel of the Florida Strait (FS) to a topographically stabilized jet along a boundary in the South Atlantic Bight (SAB) upstream of Cape Hatteras, and finally to a free, meandering, eddy-shedding jet downstream of Cape Hatteras in the Middle Atlantic Bight (MAB) and farther downstream. Gulf Stream structure and transport evolve markedly across these differing dynamical regimes (e.g., Meinen and Luther 2016). It has long been known that Gulf Stream volume transport increases in the downstream direction (Knauss 1969); transport approximately triples between the Florida Strait and the open North Atlantic downstream of Cape Hatteras (Leaman et al. 1989). Estimated full-depth transport increases from about $32 \mathrm{~Sv}\left(1 \mathrm{~Sv} \equiv 10^{6} \mathrm{~m}^{3} \mathrm{~s}^{-1}\right)$ in the 
Florida Strait (Meinen et al. 2010), to about 94 Sv near Cape Hatteras (Leaman et al. 1989), and to at least $150 \mathrm{~Sv}$ near $60^{\circ} \mathrm{W}$ (Hogg 1992). Meanders north of Cape Hatteras generally grow in the downstream direction (Watts and Johns 1982), although a local minimum in meander amplitude is found between the CMV Oleander survey line near $70^{\circ} \mathrm{W}$ and Line $\mathrm{W}$ near $68^{\circ} \mathrm{W}$ (Cornillon 1986; Joyce et al. 2000; Andres et al. 2020).

Many observational campaigns have focused on capturing Gulf Stream dynamics at fixed stations or with repeat ship-based transects. A variety of Gulf Stream transport estimates have been produced from observational efforts at certain positions along the Gulf Stream's path and with relatively short temporal extent (e.g., Halkin and Rossby 1985; Hall and Bryden 1985; Leaman et al. 1989; Hogg 1992; Johns et al. 1995). Measurements of Gulf Stream transport spanning a decade or longer are only available for three locations in the Gulf Stream: at the Florida Cable (FC) in the Florida Strait since 1982 (Baringer and Larsen 2001; Shoosmith et al. 2005; Meinen et al. 2010), along the Oleander line since 1992 (Flagg et al. 2006; Andres et al. 2020), and at Line W from 2004 to 2014 (Toole et al. 2011, 2017; Andres et al. 2020). These longterm observations are separated by more than $1500 \mathrm{~km}$ in the along-stream direction (Fig. 1) and thus do not resolve the space-time evolution of Gulf Stream transport across the varying dynamical regimes along the U.S. East Coast.

Gulf Stream transport variability may not be correlated between different dynamical regions; Sanchez-Franks et al. (2014) found that volume transport in the Florida Strait is uncorrelated with transport downstream of Cape Hatteras. This lack of correlation indicates varying entrainment along the Gulf Stream's path and points to the importance of recirculation gyres (e.g., Johns et al. 1995; Andres et al. 2020). Large, eddy-driven recirculations at depth exist both north (Richardson 1985; Hogg 1992) and south (Worthington 1976) of the Gulf Stream, contributing 20-40 Sv to the total transport (Hogg et al. 1986; Johns et al. 1995). Smaller upper-ocean recirculation cells have also been observed just downstream of the Gulf Stream's separation point at Cape Hatteras (Csanady and Hamilton 1988; Andres et al. 2020). The Antilles Current, which joins the Gulf Stream just north of the Bahamas, is another highly variable source of waters that are entrained into the Gulf Stream (Meinen et al. 2019).

Studies at isolated locations along the U.S. East Coast reveal differences in the properties of waters constituting the Gulf Stream. Meinen and Luther (2016) noted distinct upper and lower layers in the Florida Strait and three distinguishable layers downstream of Cape Hatteras when comparing full-depth observations from both locations. Farther downstream, at $42^{\circ} \mathrm{N}$ near the Southeast Newfoundland Ridge, the Gulf Stream structure

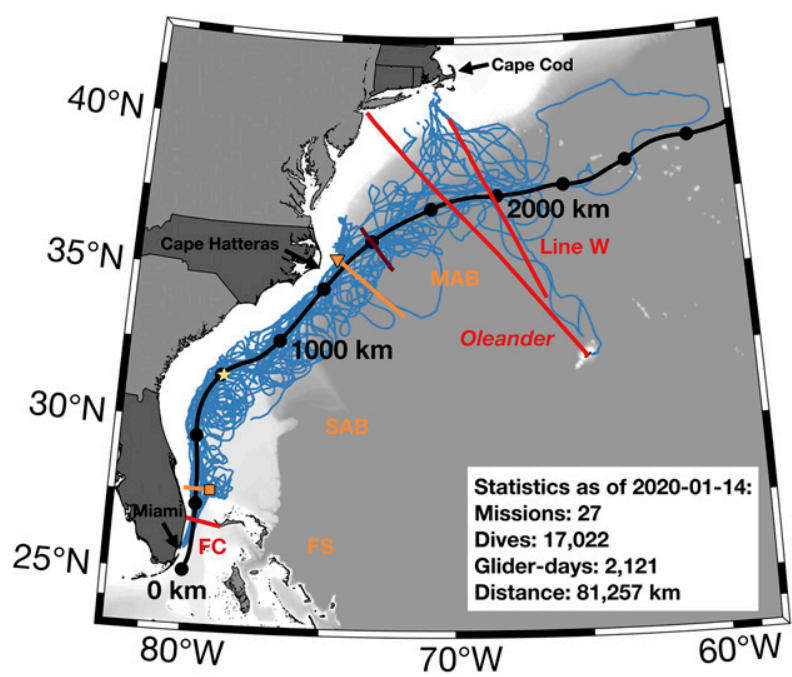

FIG. 1. Trajectories of Spray glider missions in the Gulf Stream (blue). Locations of sustained in situ Gulf Stream observations from other programs (red): the Florida Cable (FC) a part of the Western Boundary Time Series; the Oleander line; and Line W. The mean 40-cm SSH contour averaged over 16 calendar years (1 Jan 2004-31 Dec 2019) represents the mean Gulf Stream position and provides an along-stream coordinate system (black with dots every $250 \mathrm{~km}$ ). Orange lines delineate different dynamical regions: the Florida Strait (FS), South Atlantic Bight (SAB), and Middle Atlantic Bight (MAB). The orange triangle indicates the location of "The Point" near Cape Hatteras, and the orange square shows the northwesternmost point of Little Bahama Bank at the 500-m isobath. The yellow star denotes the location of the Charleston Bump. The PEGASUS line near $73^{\circ} \mathrm{W}$ is shown in maroon. From south to north, Florida, North Carolina, and the New England states are highlighted in dark gray, and important locations are indicated with arrows. Glider mission statistics are displayed in the lower right.

returns to two distinguishable layers (Meinen and Luther 2016). Among the water masses advected and modified within the Gulf Stream are intermediate waters, including Antarctic Intermediate Water and Labrador Sea Water. Labrador Sea Water is formed through deep convection in the Labrador Sea and is transported southward in the uppermost layer of the deep western boundary current (DWBC; Le Bras et al. 2017). The shallowest component of Labrador Sea Water, often called upper Labrador Sea Water, is prone to interactions with the Gulf Stream when the DWBC encounters the Gulf Stream near Cape Hatteras (Pickart and Smethie 1993; Spall 1996; Bower and Hunt 2000). AAIW is formed remotely at high southern latitudes and reaches the Gulf Stream through the Florida Strait. Szuts and Meinen (2017) classified the volume transport through the Florida Strait based on water masses, but the along-stream evolution of water mass transport and the details of the varying inputs to total Gulf Stream transport remain unknown downstream of the Florida Strait.

Due to the large gradients and relatively small horizontal scales of the Gulf Stream, concurrent, high-resolution 


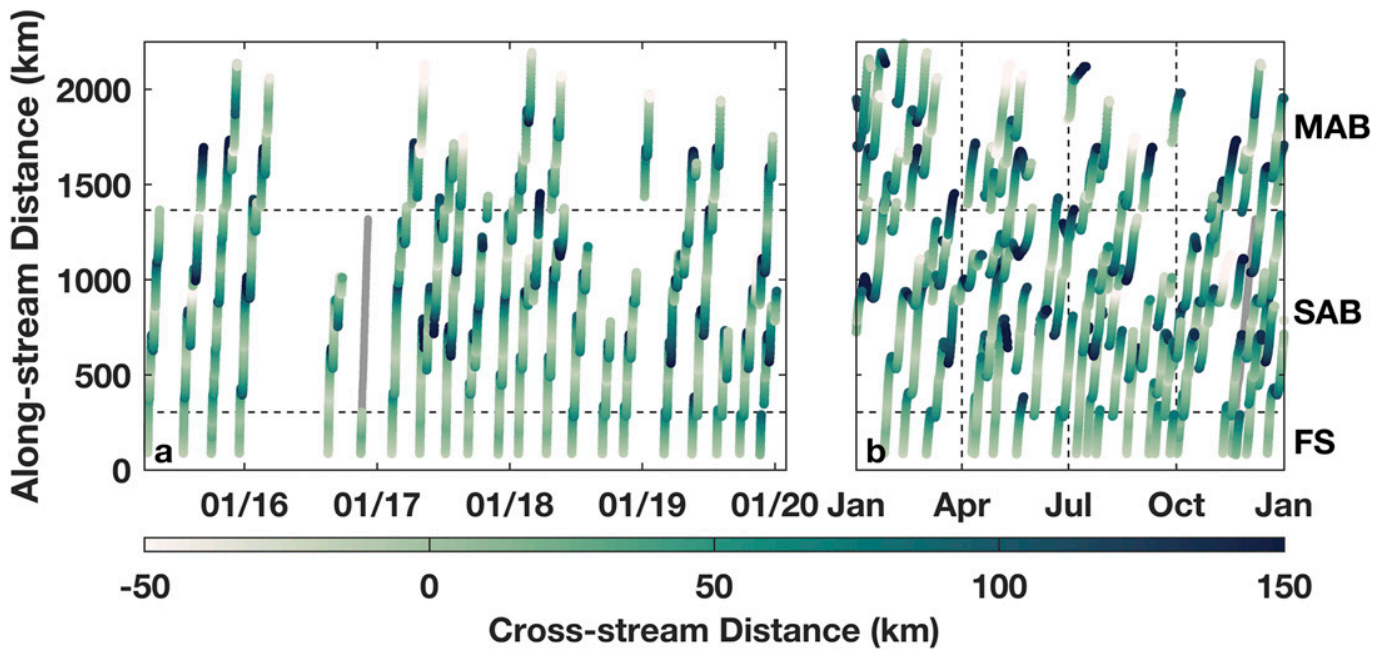

FIG. 2. Spray glider sampling in the Gulf Stream as a function of along-stream distance from $25^{\circ} \mathrm{N}$ and time. (a) Sampling from Apr 2015 through Jan 2020. (b) All sampling since 2004 as a function of time of year instead of measurement date. Vertical and horizontal dashed lines delineate seasons and dynamical regions (FS, SAB, MAB), respectively. Points are colored by cross-stream position relative to where the $15^{\circ} \mathrm{C}$ isotherm is found at a depth of $200 \mathrm{~m}$, except for part of one glider mission in late 2016 when the CTD failed (gray).

observations of hydrography and velocity are necessary to examine how different water masses contribute to total Gulf Stream transport. In the Gulf Stream along the U.S. East Coast, an extensive field program using autonomous underwater gliders (Todd et al. 2016; Todd 2017; Todd and Locke-Wynn 2017; Todd et al. 2018) provides routine, finescale, subsurface measurements of hydrography and velocity over more than $15^{\circ}$ of latitude. These observations provide a detailed picture of the upper kilometer of the Gulf Stream's structure and fill the gap between long-term measurements in the Florida Strait and downstream of Cape Hatteras (Fig. 1).

Here we examine the along-stream evolution of Gulf Stream volume transport across different dynamical regimes along the U.S. East Coast. The transport estimates presented here are derived from a combination of glider-based observations and shipboard measurements along Line $\mathrm{W}$ that are described in section 2. Section $3 \mathrm{a}$ explains how we estimate volume transport from the observations, then discusses the along-stream increase in total volume transport with comparisons to previous studies. Section $3 \mathrm{~b}$ focuses on the contributions of waters with various properties to Gulf Stream transport. Section 4 summarizes the results and implications.

\section{Observations}

\section{a. Glider missions}

Spray autonomous underwater gliders (Sherman et al. 2001; Rudnick et al. 2016) have repeatedly surveyed the Gulf Stream along the U.S. East Coast over the course of 27 missions since 2004 (Fig. 1). Between 2004 and 2009 , four missions sampled exclusively downstream of Cape Hatteras (details in Todd et al. 2016). Since 2015, 23 missions have sampled along the U.S. East Coast between Miami, Florida, and New England. For the ongoing sampling program, gliders are deployed offshore of Miami near $25^{\circ} 45^{\prime} \mathrm{N}, 80^{\circ} \mathrm{W}$ approximately every two months (Fig. 2a) to ensure sufficient seasonal coverage (Fig. 2b). During a typical 120-day mission, a glider crosses the Gulf Stream approximately 10 times between the Florida Strait and the continental shelf south of Cape Cod, Massachusetts, while profiling along a sawtooth path through the water column. Since June 2018, gliders have had clearance to enter Bahamian waters, allowing occupation of complete transects across the Florida Strait. Some missions ended early due to shark attacks and instrument failures, leading to reduced observation density downstream of Cape Hatteras (Fig. 2). This analysis uses observations from all Gulf Stream glider missions completed through January 2020; summary mission statistics are included in Fig. 1.

The horizontal speed of the gliders through the water is approximately $0.25 \mathrm{~m} \mathrm{~s}^{-1}$, but depth-average Gulf Stream speeds often exceed $1 \mathrm{~m} \mathrm{~s}^{-1}$. The gliders are thus advected downstream while they steer perpendicular to the observed depth-average currents. Resulting trajectories over the ground are typically oriented at angles of $25^{\circ}-40^{\circ}$ to the left or right of the local flow while crossing the Gulf Stream (Fig. 1; Todd et al. 2016). Gliders are often commanded to loop upstream on the flanks of the Gulf Stream to achieve denser along-stream resolution. 


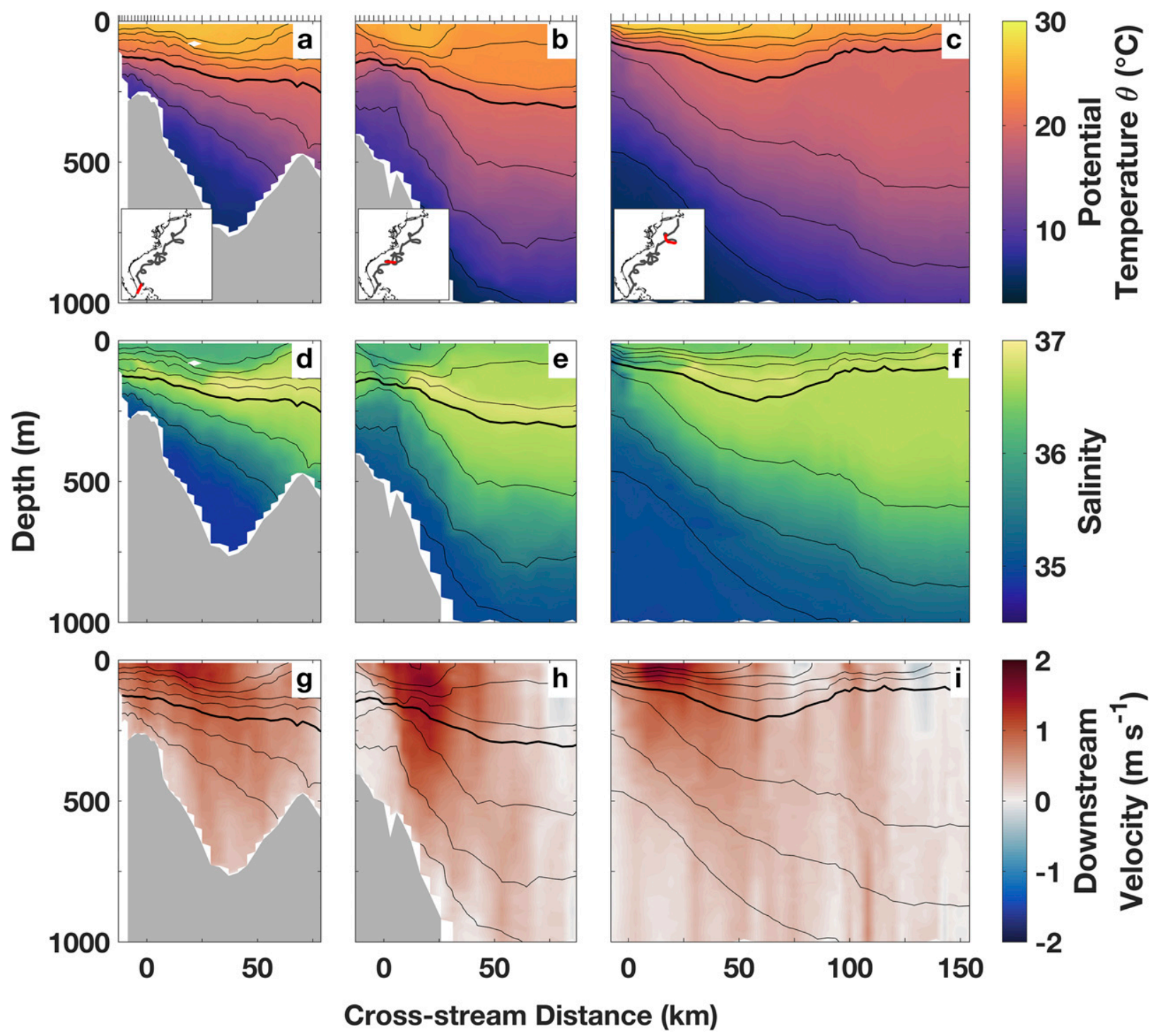

FIG. 3. Example Spray glider transects across the Gulf Stream during spring 2019: (a)-(c) potential temperature $\theta$, (d)-(f) salinity, and (g)-(i) downstream velocity (i.e., velocity parallel to the measured depth-average current). Black contours are isopycnals with a spacing of $0.5 \mathrm{~kg} \mathrm{~m}^{-3}$ and the $26.0 \mathrm{~kg} \mathrm{~m}^{-3}$ isopycnal bold. Tick marks on the upper axes indicate the locations of individual profiles. The bathymetry as measured by the glider's AD2CP is shaded gray. From left to right, transects are representative of the FS, SAB, and MAB dynamical regions. Inset maps in (a)-(c) show the location of each transect in red in relation to the complete mission trajectory (gray).

Each glider carried a pumped Sea-Bird 41CP CTD to measure temperature, salinity, and pressure. We estimate depth-average current velocities $\mathbf{v}_{\text {DA }}$ based on the difference between dead-reckoned and GPS-measured glider displacements (Rudnick et al. 2018). For the 22 missions since July 2015 , the gliders have also been equipped with 1-MHz Nortek acoustic Doppler dual current profilers (AD2CPs) and Seapoint chlorophyll fluorometers. Some gliders began carrying Sea-Bird 63 dissolved oxygen sensors in October 2018. Chlorophyll and oxygen measurements are not discussed further here. We estimate absolute horizontal velocity profiles by combining the velocity shear measured by the AD2CPs with estimates of depth-average currents and surface drift velocities using an inverse method (Todd et al. 2017). The AD2CPs also function as altimeters and are used to avoid collisions with the seafloor during the descending phase of each glider dive. Profiles at nominal vertical speeds of $0.1 \mathrm{~m} \mathrm{~s}^{-1}$ reach to maximum depths of $1000 \mathrm{~m}$ or to within a few meters of the seafloor when the bottom is shallower than a kilometer. All quantities are measured during the ascending phase of each glider dive. Cross-Gulf Stream transects usually have a cross-stream resolution of $5 \mathrm{~km}$ or finer (e.g., Fig. 3). 

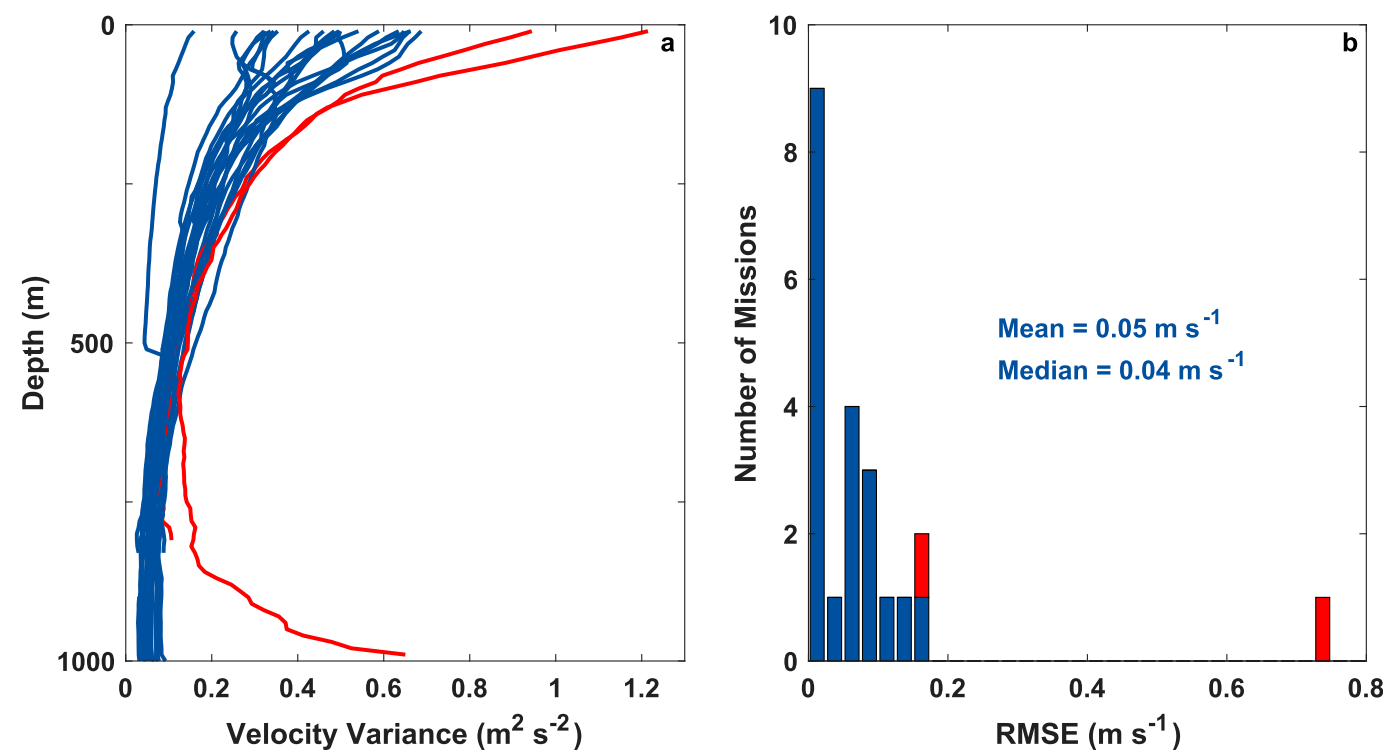

FIG. 4. (a) Vertical profiles of velocity variance for the 22 Gulf Stream glider missions with AD2CPs from the surface to the maximum depth for which at least 40 dives contribute to the variance. Red indicates missions where raw data are not available due to instrument losses. (b) Histogram of the root-mean-square error (RMSE) in velocity profiles for all Gulf Stream missions shown in (a). The mean and median RMSEs for missions with raw data are shown. Color coding is as in (a).

Glider observations are automatically and manually quality-controlled using established postprocessing routines for Spray gliders (e.g., Rudnick et al. 2017, 2018). We ensure that accurate predive and postdive locations and times are available for each dive and adjust the heading records for each dive using heading-dependent compass calibrations and local magnetic variations. CTD profiles are examined visually and quality flags are assigned manually; usable data are then averaged into $10-\mathrm{m}$ vertical bins for subsequent analyses. Raw AD2CP data are processed as described in Todd et al. (2017) to produce 10-m-resolution profiles of absolute horizontal velocity with two key changes that serve to admit more data into the velocity calculation. First, we increase the maximum velocity accepted as good from 0.5 to $5 \mathrm{~m} \mathrm{~s}^{-1}$ to avoid filtering out good data in regions of large shear (mainly around the thermocline). Second, we reduce the signalto-noise ratio (SNR) below which measurements are excluded from 20 to 1 . For two missions, loss of instruments before recovery led to no raw $\mathrm{AD} 2 \mathrm{CP}$ data being available for quality control of individual samples; only the shear profiles processed on board the gliders and transmitted in near-real time via the Iridium satellite network are available for those missions.

The accuracy of the transport estimates that follow depends in part on the accuracy of individual velocity estimates. Velocity profiles are constrained by both the depth-average velocity estimates and estimates of surface velocity from glider drift during communications (Todd et al. 2017). Depth-average velocity estimates have root-mean-square errors (RMSEs) of about $0.01 \mathrm{~m} \mathrm{~s}^{-1}$ and insignificant bias (Rudnick et al. 2018). Surface velocity estimates have accuracies of about $0.05 \mathrm{~m} \mathrm{~s}^{-1}$ (Todd et al. 2017). To estimate additional errors in depth-dependent velocities derived from $\mathrm{AD} 2 \mathrm{CP}$ measurements, we follow Todd et al. (2017) and consider the profiles of velocity variance for each glider mission with an AD2CP (Fig. 4a). A velocity variance profile in the ocean is expected to have high variance near the surface due to upperocean variability and to generally decrease with depth. However, the glider-based variance profiles often exhibit a minimum at middepth. The increase in variance below this middepth minimum in the glider velocity solutions is attributed to random errors (e.g., due to reduced acoustic scatterers at depth). We estimate the root-mean-square error associated with the depth-dependent velocity profiles from a mission as the square root of the difference between the minimum variance and the maximum variance below the depth of minimum variance. Here, the variance profiles taken into account extend down to the maximum depth sampled during at least 40 glider dives over the course of each mission. For 9 of 22 missions, minimum variance is at the bottom of the profile. The two updates to AD2CP processing since Todd et al. (2017) (i.e., reduction of SNR ratio and increase of maximum velocity accepted as good) admit more data into the estimate, thereby reducing profile-to-profile variability, especially at depth. Increases in velocity variance at depth and resulting estimates of root-mean-square errors in depth-dependent velocity are reduced from the $0.24 \mathrm{~m} \mathrm{~s}^{-1}$ 
estimate for a Gulf Stream mission in Todd et al. (2017) to less than $0.18 \mathrm{~m} \mathrm{~s}^{-1}$ for all missions with raw AD2CP data available (Fig. 4b, blue). The two missions without raw $\mathrm{AD} 2 \mathrm{CP}$ data exhibit higher variance and consequently higher root-mean-square errors (Fig. 4, red). One mission had very low variance at the surface due to many shallow dives over the continental shelf. For missions with raw $\mathrm{AD} 2 \mathrm{CP}$ data available, the mean error associated with the depth-dependent, AD2CP-derived velocity profiles is $0.05 \mathrm{~m} \mathrm{~s}^{-1}$ and the median is $0.04 \mathrm{~m} \mathrm{~s}^{-1}$. Considering these various sources contributing depthdependent and absolute errors, we will assume that $0.1 \mathrm{~m} \mathrm{~s}^{-1}$ is an appropriate typical value for the error in individual glider-based absolute velocity profiles in the transport estimates that follow.

For the five missions without AD2CPs, depth-dependent, cross-transect velocities are estimated from geostrophic shear referenced to the cross-track component of the depth-average current following Todd et al. (2011). We use an objective mapping routine with a 50-km Gaussian length scale (Bretherton et al. 1976) to filter signals with periods shorter than a day, such as internal waves and tides (Rudnick and Cole 2011; Todd et al. 2011), when estimating along-track density gradients at the original profile locations. Temperature and salinity for these transects are mapped similarly. We mask objectively mapped fields where the normalized mean square error of the objective map exceeds 0.1. Despite difficulties near the edges of transects due to the along-track scale of the mapping, comparisons of $\mathrm{AD} 2 \mathrm{CP}$-based and geostrophic velocity estimates for missions with AD2CPs give us confidence that transport estimates derived from geostrophic velocities are useful for analysis.

\section{b. Line $W$ observations}

To supplement the glider observations, we use shipbased CTD and lowered ADCP (LADCP) measurements from 13 cruises along Line W. These observations help to constrain transport estimates in a region of reduced glider sampling downstream of Cape Hatteras (Fig. 2). Between November 1994 and May 2014, repeated cruises provided simultaneous full-depth observations of hydrographic properties and current velocities along Line W (Fig. 1; Toole et al. 2011; Andres et al. 2020). For our analysis, we require that the ship transects crossed the entire Gulf Stream and did not have large sampling gaps within the current. This leaves us with cruise data from the following times: 2003 (November), 2004 (May and September), 2005 (April), 2006 (October), 2007 (April and October), 2008 (May), 2009 (September), 2010 (October), 2011 (July), 2012 (August), 2013 (May). The Line W transects are of lower horizontal resolution than the glider

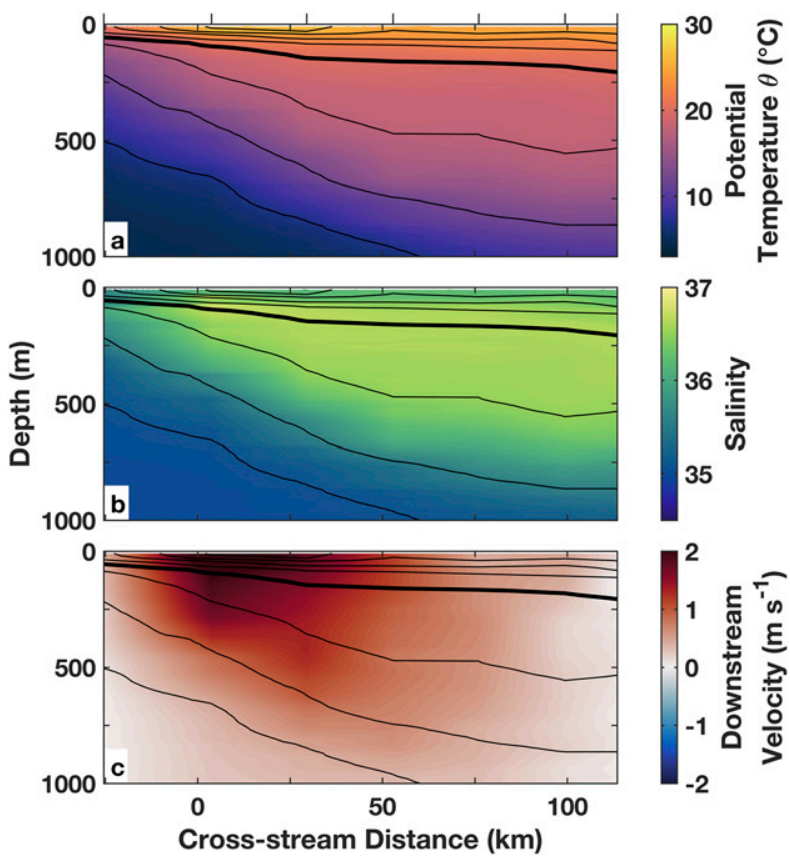

FIG. 5. Example transects of (a) potential temperature $\theta$, (b) salinity, and (c) downstream velocity in the upper $1000 \mathrm{~m}$ from Line W ship-based measurements in May 2013. Tick marks on the upper axes indicate the position of individual CTD/LADCP stations. Isopycnals are as in Fig. 3.

transects, with station spacing of about $30 \mathrm{~km}$ in the Gulf Stream (e.g., Fig. 5). To treat Line $\mathrm{W}$ transects in a manner analogous to the glider transects, we interpolate the Line $\mathrm{W}$ data in the upper kilometer to the glider depths and calculate the depth-average current as the mean LADCP-based velocity in the upper $1000 \mathrm{~m}$. As in Andres et al. (2020), near-surface gaps in LADCP profiles are filled with the shallowest valid measurement. Toole et al. (2011) report uncertainties of $0.02-0.05 \mathrm{~m} \mathrm{~s}^{-1}$ in the LADCP velocities at Line $\mathrm{W}$, comparable to the error estimates for glider-based velocities.

\section{c. Sea surface height}

Satellite-based observations of sea surface height (SSH) provide spatially broad context for the in situ observations from gliders and Line W. We use the absolute dynamic topography provided by the EU Copernicus Marine Environment Monitoring Service. Daily delayedtime products are available until 13 May 2019. Near-realtime products are used for more recent times.

\section{Results and discussion}

\section{a. Transport estimates}

Our goal is to characterize the time-mean spatial evolution of Gulf Stream volume transport above $1000 \mathrm{~m}$ along 
the U.S. East Coast using the observations from both Spray gliders and Line W. To estimate transport from this collection of cross-Gulf Stream transects we must overcome several challenges, including defining "Gulf Stream transport" and estimating the associated transport errors. In this section, we first describe how we identify cross-Gulf Stream transects [section 3a(1)], then we construct upperand lower-bound estimates of Gulf Stream transport in order to characterize errors in transport estimates [section $3 \mathrm{a}(2)$ ], and finally we discuss the along-stream evolution of the volume transport [section $3 \mathrm{a}(3)$ ].

\section{1) TRANSECT IDENTIFICATION AND ALONG-STREAM COORDINATE SYSTEM}

Our Gulf Stream transport estimates are based on estimates of transport through individual cross-Gulf Stream transects occupied by gliders throughout the domain or by a ship along Line W. Identifying discrete cross-Gulf Stream transects is the first step in our analysis. Operationally, a glider's cross-stream direction relative to the Gulf Stream is changed when the glider reaches the 100-m isobath or when depth-average currents reverse direction, allowing for navigation upstream relative to the Gulf Stream (e.g., looping glider tracks in Fig. 1). These piloting choices define initial endpoints for individual glider-based transects. For the shipboard observations along Line $\mathrm{W}$, initial transects comprise all profiles from a given cruise. To refine the individual transects from both platforms, we further require that each transect proceeds monotonically in the cross-stream direction defined by the local upper-1000-m depth-average current. The only exceptions are isolated midtransect glider dives that proceed in the opposite direction due to piloting mishaps. Transects are also visually inspected (in conjunction with contemporaneous SSH) to ensure that they cross the entirety of the Gulf Stream and to exclude adjacent non-Gulf Stream features.

Among the glider transects excluded from this analysis are those that only crossed part of the Florida Strait prior to receipt of Bahamian clearance and those south of New England that were cut short near the ends of the missions due to limits on mission endurance. Furthermore, one glider mission starting in November 2016 is excluded entirely due to a CTD failure before completion of a full Gulf Stream crossing. In total, 155 glider transects and 13 Line $\mathrm{W}$ transects are used for transport estimates. Of the glider transects, 142 have $\mathrm{AD} 2 \mathrm{CP}$-based velocity estimates and 13 only have geostrophic velocity estimates.

Following Todd et al. (2016), a local streamwise coordinate system is constructed for each glider and Line $\mathrm{W}$ transect with the cross-stream origin located where

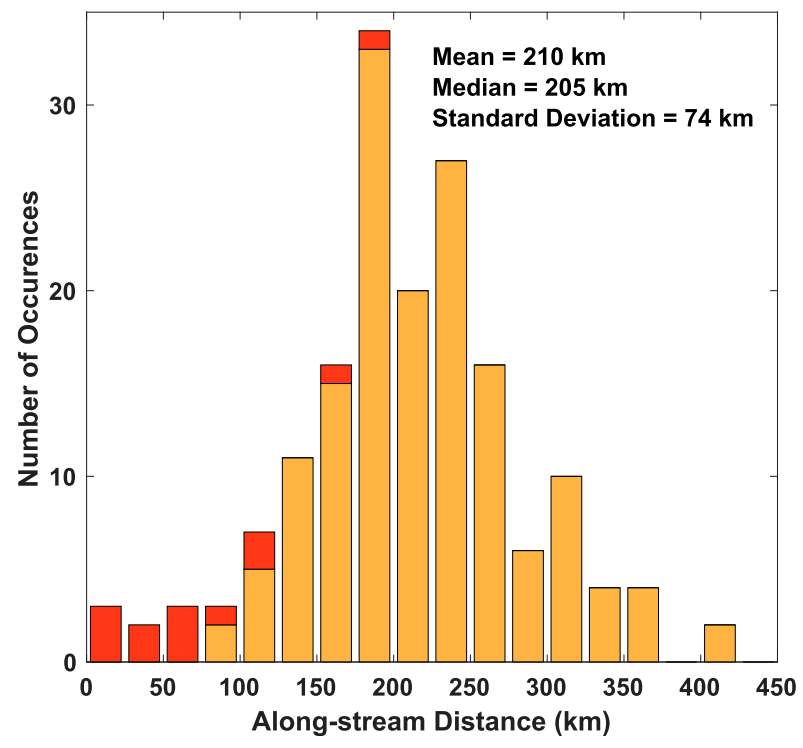

FIG. 6. Histogram of the along-stream distances covered during all glider (orange) and Line W (red) transects that are used for transport calculations. The mean, median, and standard deviation of along-stream extent are given in the upper-right corner.

the $15^{\circ} \mathrm{C}$ isotherm is found at a depth of $200 \mathrm{~m}$, a common definition of the Gulf Stream's North Wall (Fuglister and Voorhis 1965). The along-stream extent of each transect is computed as the sum of the along-stream displacements relative to the depth-average current during each dive in a transect. The typical along-stream extent of a gliderbased cross-Gulf Stream transect is about $200 \mathrm{~km}$ (orange bars in Fig. 6). The along-stream extent of Line W transects is often much shorter (red bars in Fig. 6) because Line $\mathrm{W}$ is oriented approximately perpendicularly to the Gulf Stream in most cases. The mean along-stream extent across all transects is $210 \mathrm{~km}$, the median is $205 \mathrm{~km}$, and the standard deviation is $74 \mathrm{~km}$.

We define an along-stream coordinate system based on the 40-cm SSH contour averaged over 16 calendar years that cover almost the entire observation period (1 January 2004-31 December 2019). The long-term mean position of the $40-\mathrm{cm} \mathrm{SSH}$ contour is treated as a representative streamline that traces the Gulf Stream continuously from Florida to beyond Cape Hatteras (Fig. 1). Other SSH contours that are frequently used to track the Gulf Stream [e.g., the 25-cm SSH contour in Lillibridge and Mariano (2013) and Andres (2016)] are not continuous over the entire glider sampling domain. The intersection of the $40-\mathrm{cm} \mathrm{SSH}$ contour with $25^{\circ} \mathrm{N}$, a point in the Florida Strait close to the typical launch site for gliders, is taken as the origin of our along-stream coordinate system. Projecting the midpoint of a transect onto the along-stream coordinate system gives a measure of the approximate along-stream position of each 
Gulf Stream transect, though it should be reiterated that glider-based transects typically have along-stream extents of $200 \mathrm{~km}$. The along-stream distances of other important geographic locations and transport measurement sites (Fig. 1) are defined as the intersection with the along-stream coordinate system for lines (e.g., the Florida Cable, the PEGASUS line near $73^{\circ} \mathrm{W}$, the Oleander line, and Line $\mathrm{W}$ ) or the projection onto the along-stream coordinate system for points [e.g., the Charleston Bump (CB), a ridge and trough feature in the continental slope near $31^{\circ} 30^{\prime} \mathrm{N}, 79^{\circ} \mathrm{W}$ indicated as a yellow star in Fig. 1]. To distinguish the different geographical regions (FS, SAB, MAB), we project the northwesternmost tip of the Little Bahama Bank at the $500-\mathrm{m}$ isobath $\left(27^{\circ} 41^{\prime} \mathrm{N}, 79^{\circ} 14^{\prime} \mathrm{W}\right.$, orange square in Fig. 1) and "The Point" at Cape Hatteras $\left(\mathrm{CH} ; 35^{\circ} 33^{\prime} \mathrm{N}\right.$, $74^{\circ} 48^{\prime} \mathrm{W}$, orange triangle in Fig. 1) onto the along-stream coordinate system. The resulting along-stream distances of those two locations are 304 and $1366 \mathrm{~km}$, respectively. Transects with along-stream distances smaller than that of the Little Bahama Bank are considered Florida Strait transects (10 transects used in the transport calculations). Transects with along-stream distances larger than that of the Little Bahama Bank and smaller than that of The Point are considered SAB transects (111 transects). The rest are MAB transects (47 transects). The alongstream extent of glider transects creates ambiguity in their positioning, particularly in classification between geographic regions; for example, initial transects from Miami sometimes extend north of the Little Bahama Bank and capture flow of the Antilles Current that joins the Gulf Stream downstream of the Florida Strait, yet the midpoint of the transect is within the Florida Strait. The impact of this ambiguity is reduced by averaging transport estimates from many transects in section $3 \mathrm{a}(3)$.

\section{2) Gulf Stream transport CALCULATIONS}

The Gulf Stream volume transport $T$ through any given cross-Gulf Stream transect is defined as the area integral of the velocity $v_{\perp}$ that is perpendicular to the transect

$$
T=\iint_{A} v_{\perp} d A
$$

where the region $A$ defines the Gulf Stream. For discrete sampling, $T$ is estimated as

$$
T=\sum_{i} \sum_{j} T_{i j}
$$

the sum of the transports $T_{i j}$ through each measurement cell within the bounds of the Gulf Stream. Our coordinate system is such that $T_{i j}$ is positive downstream for the Gulf Stream; we include only $T_{i j}>0$ in our summation.

The fundamental challenge in estimating the transport of the Gulf Stream (or any other particular current) lies in defining the portion of the total transport through a transect that is to be included in the summation in Eq. (2) (see also Knauss 1969; Rossby et al. 2010). The Gulf Stream can exhibit substantial curvature in its path (e.g., Hansen 1970; Levine et al. 1986; Johns et al. 1989), while corotating eddies are frequently located along the edges of the current (Lee and Atkinson 1983; Glenn and Ebbesmeyer 1994). In several cases, the direction of the depth-average flow curves more than $90^{\circ}$ over the span of a glider transect (e.g., Fig. 7a). These large curvatures are often encountered downstream of Cape Hatteras, as well as in the area around the Charleston Bump (e.g., Fig. 7a). The Charleston Bump has been shown to play a role in turning the Gulf Stream through bottom pressure torque (Gula et al. 2015). Curvature is a challenge because defining a single "downstream" direction becomes problematic for transects that are not oriented perpendicularly to the Gulf Stream, whether due to platform advection as for gliders or meandering of the current relative to the fixed Line W location. Similarly, corotating eddies are a challenge because we need to decide which portion of the flow contributes to poleward transport or "throughput." To overcome these difficulties, we construct upper- and lower-bound estimates for the Gulf Stream transport through each transect.

For an upper-bound estimate of volume transport, we aim to include the maximum possible transport, so we simply define

$$
T_{i j \text {,upper }}=v_{\perp i j} \Delta l_{i} \Delta z
$$

where $v_{\perp i j}=\left|\mathbf{v}_{i j}\right| \sin \left(\phi_{i j}-\alpha_{i}\right)$ denotes the component of the measured velocity that is perpendicular to the local transect segment $\Delta \mathbf{l}_{i}$ (see Fig. 7b); $\Delta l_{i}$ is the length of $\Delta \mathbf{I}_{i}$. The angles $\phi$ and $\alpha$ are measured counterclockwise from east to the local current direction $\mathbf{v}$ and the transect segment $\Delta \mathbf{l}$, respectively; $\Delta z=10 \mathrm{~m}$ is the vertical extent of each sampling bin. To compute transport as a function of density rather than depth, we linearly interpolate $v_{\perp}$ to isopycnal surfaces with a spacing of $0.05 \mathrm{~kg} \mathrm{~m}^{-3}$ and replace $\Delta z$ with $\Delta \sigma=0.05 \mathrm{~kg} \mathrm{~m}^{-3}$ in Eq. (3). For the glider observations, $\Delta \mathbf{l}$ is the displacement between the GPS fixes recorded at the beginning and end of a dive. For Line $\mathrm{W}$ data, we calculate the displacement $\Delta \mathbf{I}$ from midpoints between the stations that serve as artificial predive/postdive locations. This upper bound is equivalent to cross-stream integration of all flow parallel to the local depth-average current for each profile (e.g., integrating Figs. 3g-i). All flow constituting a curved Gulf 


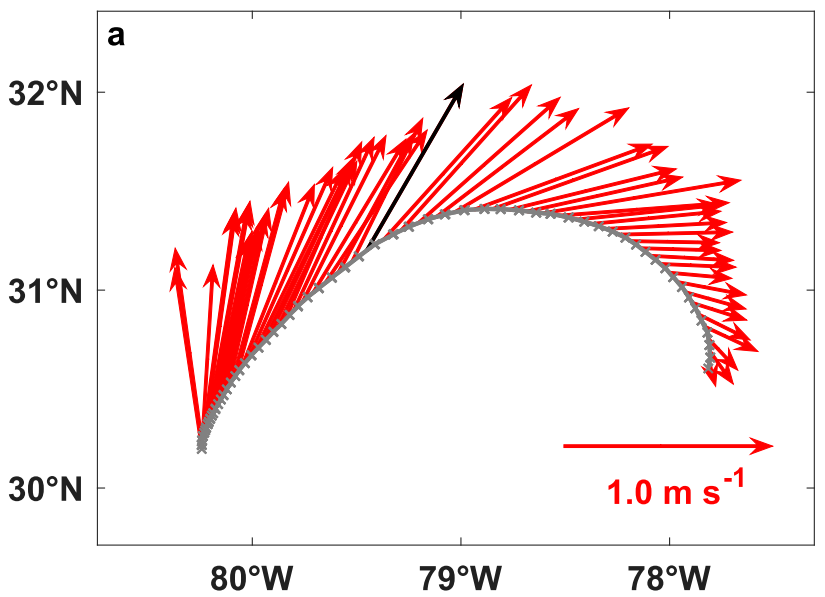

b

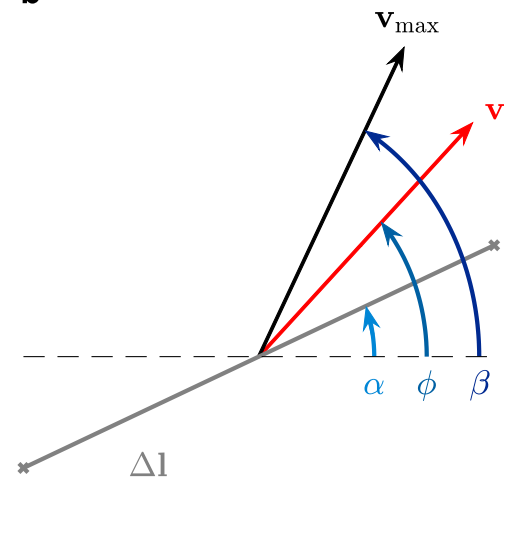

FIG. 7. (a) Example transect from a mission near $31^{\circ} \mathrm{N}$ during July 2015 . Gray line segments correspond to the glider displacements $\Delta \mathbf{I}$ during each dive with locations of GPS fixes denoted by crosses. Depth-average currents $\mathbf{v}_{\text {DA }}$ for each dive are shown as red arrows. The dive with the maximum transport per unit distance for the entire transect $\mathbf{v}_{\text {max }}$ is highlighted in black. A unit arrow is shown for scale in the lower-right corner. (b) Zoomed version of (a) showing only a single glider dive to highlight the vectors and angles used to calculate transport. The vector $\mathbf{v}$ represents the local current, $\alpha$ is the angle of the glider displacement, $\phi$ is the angle of the local current, and $\beta$ is the angle corresponding to $\mathbf{v}_{\max }$. All angles are measured counterclockwise from east.

Stream is included (e.g., all transport in the direction of the red arrows in Fig. 7a), but flow as part of nearby eddies, including flow not in the same direction as the Gulf Stream, is also included when those eddies remain within selected transects.

For a lower-bound estimate of volume transport, we seek to exclude the contributions due to adjacent eddies and flow in directions other than that of the Gulf Stream. We accomplish this by scaling each $T_{i j \text {,upper }}$ based on the angle between the local flow and a chosen representative orientation of the Gulf Stream for that transect. We define

$$
T_{i j \text { lower }}=T_{i j, \text { upper }} \cos \left(\phi_{i j}-\beta\right),
$$

where $\beta$ is the orientation of $\mathbf{v}_{\max }$, the depth-average current for the profile with the maximum transport per unit along-track distance for a given transect (e.g., black arrow in Fig. 7). Transport per unit along-track distance is simply the depth-average speed $\left|\mathbf{v}_{\text {DA }}\right|$ times the profile depth $H$. For transects in which the depth-average current is strongest in shallow regions near the edges of the transect and the Gulf Stream is curved (e.g., Fig. 7a), this definition of $\mathbf{v}_{\max }$ better captures the direction of the core of the Gulf Stream than choosing the direction of the maximum depth-average current to define $\beta$. We use this technique for our lower-bound estimate since it guarantees a smaller total transport $\left[\cos \left(\phi_{i j}-\beta\right) \leq 1\right]$ than the upper bound, whereas attempting to compute transport in a streamwise coordinate system may lead to larger or smaller transport estimates when nonparallel flow exists (see Halkin and Rossby 1985). The lowerbound at least partially excludes contributions from corotating eddies, since only transport into the direction of the Gulf Stream core (i.e., $\mathbf{v}_{\max }$ ) is considered. Flow that is oriented more than $90^{\circ}$ from $\mathbf{v}_{\text {max }}$ makes no contribution to the lower-bound transport estimate.

Having estimated the $T_{i j}$ for both our upper- and lowerbound transports, we next determine the limits of integration [area $A$ in Eq. (1)]. We look for a 4-connected region (i.e., pixels share adjoining edges) of $T_{i j}>0$ using edge-finding methods adapted from image processing. Figure 8 shows a step-by-step example of the process by which we determine the integration limits. From the $T_{i j}$ (Fig. 8a), we create a binary matrix that has value 1 when $T_{i j}>0$ and 0 otherwise (Fig. 8b). Horizontal and vertical differences of this matrix allow for unambiguous identification of sampling cells (pixels) that are along the edges of connected regions; each pixel is labeled with a binary code describing whether it is a left, right, top, and/or bottom edge of, interior to, or exterior to a connected region of $T_{i j}>0$ (Fig. 8b). We then trace and label edge pixels while requiring 4-connectivity (i.e., pixels have to be connected to their regions through at least one edge and not only a corner). Starting from an identified edge pixel, we determine the location of the next connected edge pixel based on the label of the current pixel. After completing a circuit along connected edges, we assign a unique label to the resulting connected region. The process is repeated starting from an uncategorized edge pixel until all pixels with $T_{i j}>0$ are assigned to connected regions (Fig. 8c). The region 

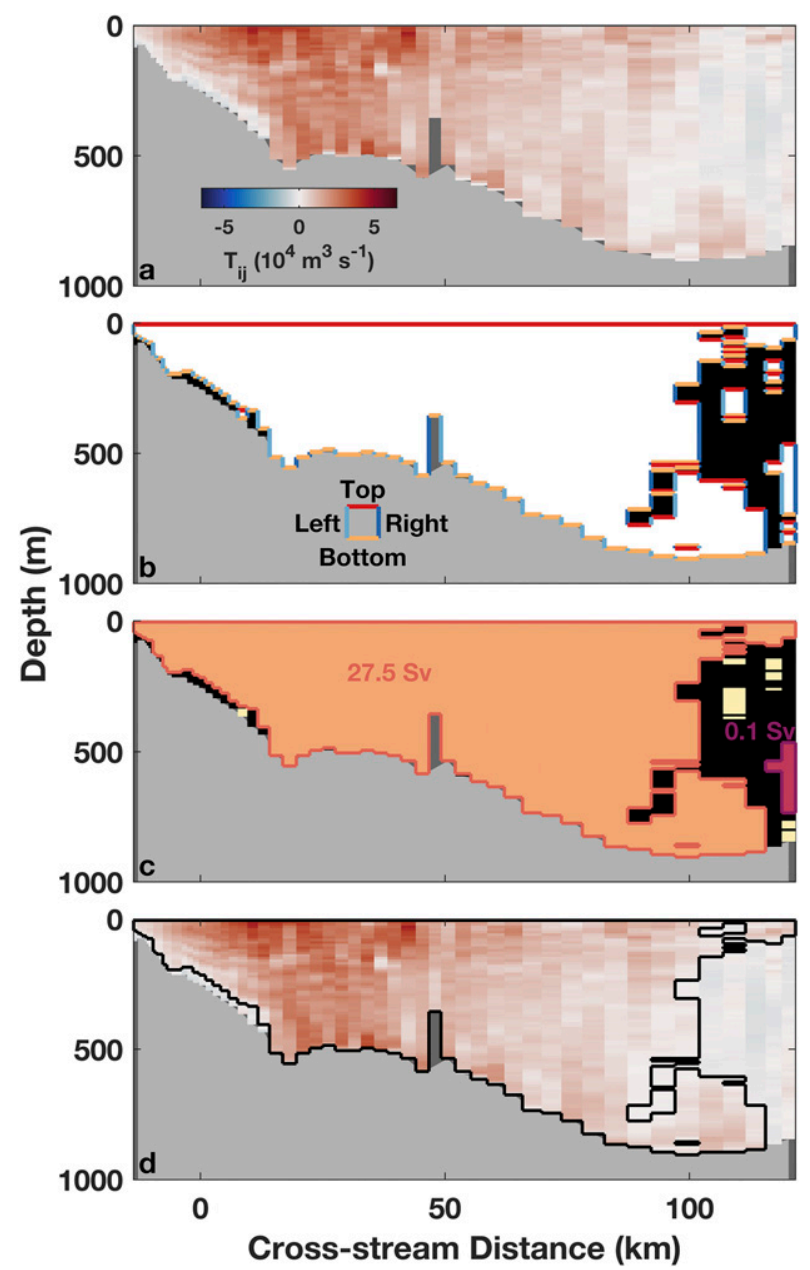

FIG. 8. Step-by-step example illustrating the procedure for determining limits of integration for transport calculations in Eq. (1). The bathymetry as measured by the glider's AD2CP is shaded light gray. Dark gray indicates regions where there are no data. (a) $T_{i j \text {,lower }}$ for the transect shown in Fig. 7a. (b) Binary matrix that has value 1 (white) when $T_{i j}>0$ and 0 otherwise (black). Top/bottom/left/right edges of regions of positive $T_{i j}$ are drawn in indicated colors. (c) Connected regions of positive $T_{i j}$ and their correspondingly colored edges. The orange region with the largest transport is the Gulf Stream, the magenta region contains the second largest transport. Regions with smaller transports are shown in yellow. As in (b), black indicates regions where $T_{i j}$ is negative. (d) $T_{i j}$ as in (a) with the resulting integration boundary of the Gulf Stream in black.

with the largest transport within a transect is taken to be the Gulf Stream and its edge is the limit of integration for the Gulf Stream transport estimate (Fig. 8d).

Two example transects illustrate the effect of the upper and lower bound definitions on volume transport estimates (Fig. 9). For a transect with almost no curvature in the Florida Strait (Fig. 9a), the $T_{i j \text {,upper }}$ and $T_{i j \text {,lower }}$ are essentially the same (Figs. 9c,e) and the resulting upper- and lower-bound transport estimates of
36.8 and $36.4 \mathrm{~Sv}$, respectively, are almost equal. On the other hand, for a transect with strong curvature near $31^{\circ} \mathrm{N}$ in the vicinity of the Charleston Bump (Fig. 9b), the two $T_{i j}$ fields and the corresponding integration limits differ substantially (Figs. 9d,f), resulting in volume transport estimates that differ by about $15 \mathrm{~Sv}$.

Upper- and lower-bound volume transport estimates are computed for each individual glider and Line W transect following the procedure above (circles and squares in Fig. 10). We use AD2CP-based velocities for the glider transport calculations when available (142 transects; filled circles) and geostrophic velocity estimates otherwise (13 transects; open circles). Line W transport estimates are based on velocities measured by LADCPs (13 transects; squares).

To assess the effect of instrumental errors on our transport estimates, we propagate the $0.1 \mathrm{~m} \mathrm{~s}^{-1} \mathrm{er}$ rors on glider-based velocity profiles (see section $2 \mathrm{a}$ ) and the $0.05 \mathrm{~m} \mathrm{~s}^{-1}$ errors on Line W LADCP profiles (section 2b) through the transport estimates for each transect. The resulting mean and standard deviation of errors is $0.4 \pm 0.1 \mathrm{~Sv}$ for both types of estimates and both bounds. Although the uncertainty in LADCP velocity estimates is smaller than the uncertainty in glider-based $\mathrm{AD} 2 \mathrm{CP}$ velocities, the larger station spacing results in similar transport errors. These instrumental errors are small compared to the magnitudes of the transports in question. Defining the Gulf Stream and its edges/integration bounds likely presents a larger source of uncertainty in transport estimates that is more difficult to quantify. Our construction of upper- and lower-bounds of transport estimates seeks to ameliorate this difficulty. Variability in transport on time scales shorter than the 5 days typically required to occupy a transect is not resolved. Gliderbased measurements will underestimate Gulf Stream transport when the gliders did not reach the edge of the Gulf Stream, such as in cases for which the 100-m isobath defines the inshore edge for operational reasons. However, transport contributions on the shelf are minimal even for high current velocities due to the shallow depths. Assuming current velocities of $1 \mathrm{~m} \mathrm{~s}^{-1}$, missing $10 \mathrm{~km}$ of Gulf Stream width in water shallower than $100 \mathrm{~m}$ would underestimate the transport by less than $1 \mathrm{~Sv}$.

\section{3) Along-Stream evolution of VOlume TRANSPORT}

When volume transport is plotted as a function of the along-stream position for each transect, the wellknown increase in volume transport between the Florida Strait and New England becomes apparent (circles and squares in Fig. 10). However, both upper- and lowerbound transport estimates exhibit significant variation between transects at similar along-stream positions. As 


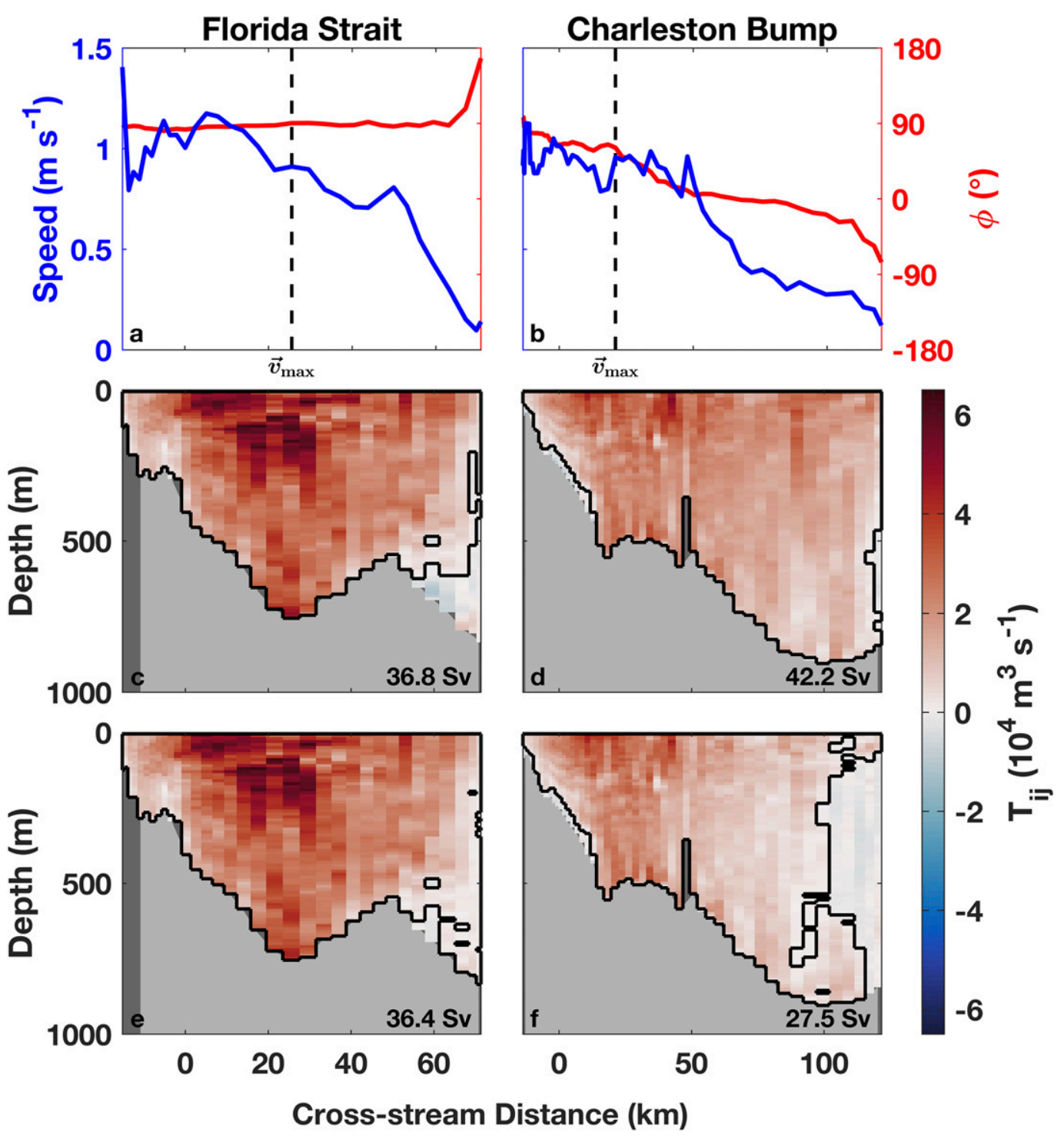

FIG. 9. Two example transects across the Gulf Stream (left) from the Florida Strait and (right) in the vicinity of the Charleston Bump (same transect as shown in Figs. 7 and 8). (a),(b) Speed (blue) and direction clockwise from east ( $\phi$; red) of depth-average currents. The location of $\mathbf{v}_{\max }$ is indicated by dashed vertical black lines. (c),(d) Upper bound of the transport through each cell $\left(T_{i j, \text { upper }}\right)$. (e),(f) lower- bound of the transport through each cell $\left(T_{i j \text {,lower }}\right)$. In (c)-(f), the black line outlines the region of integration for transport calculations. Light gray indicates the bathymetry as measured by the glider's $\mathrm{AD} 2 \mathrm{CP}$, while regions without data are dark gray. Corresponding volume transport estimates are shown in the lower right of (c)-(f).

Rossby et al. (2010) noted, interpreting transport variations between successive transects is difficult if the transects do not reach the physical boundaries of a basin or channel. This transect-to-transect variability at fixed along-stream positions, noted early on by Iselin (1940), is attributable to eddy activity, inherent Gulf Stream variability, and other variable forcing including hurricanes (e.g., Todd et al. 2018).

To estimate time-mean Gulf Stream transport as a function of along-stream distance, we smooth over the transect-to-transect variability using a running weighted mean with a Gaussian window that has a characteristic length scale of $200 \mathrm{~km}$. This along-stream smoothing scale is chosen based on the typical along-stream extent of individual cross-Gulf Stream glider transects (Fig. 6), which sets a lower limit on the along-stream resolution of our transport estimates. This $200-\mathrm{km}$ scale is broadly consistent with previous estimates of typical length scales in the Gulf Stream from a satellite altimetry-assimilating model (Mellor and Ezer 1991). Along-stream length 


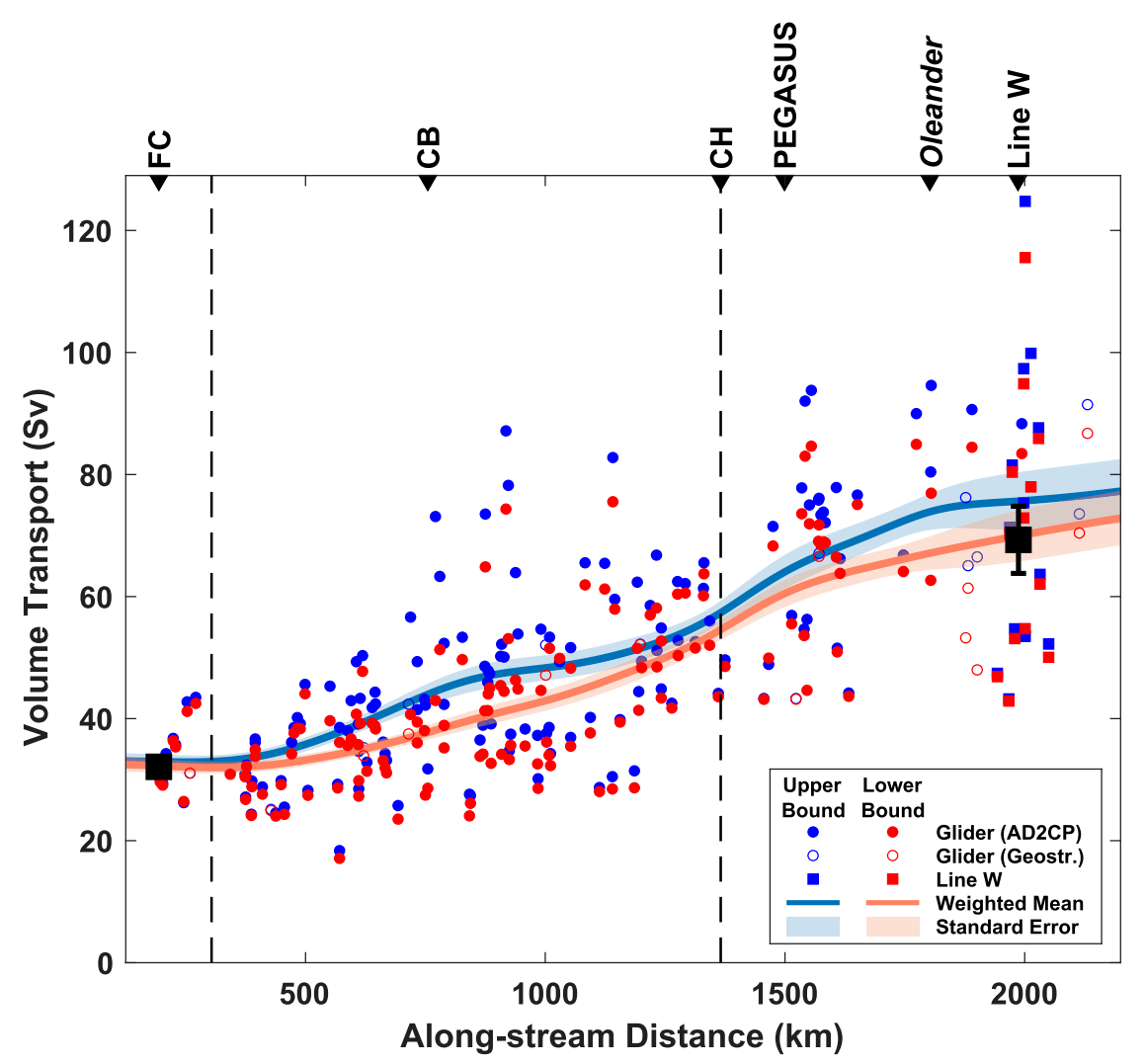

FIG. 10. Gulf Stream volume transport estimates in the upper $1000 \mathrm{~m}$ as a function of alongstream distance from $25^{\circ} \mathrm{N}$ for both the upper and the lower- bound (see legend in the lower right). Individual transport estimates (symbols) are from glider transects across the full width of the Gulf Stream (using either direct velocity measurements from AD2CPs or mapped geostrophic velocities) and from shipboard LADCP casts along Line W. A Gaussian-weighted running mean with 200-km scale (lines) and the bootstrapped standard error of the weighted mean (shading) are shown. Mean volume transport estimates from cable measurements as part of the Western Boundary Time Series in the Florida Strait (Meinen et al. 2010) and from Line W as calculated in Andres et al. (2020) are shown as black squares with whiskers indicating the standard error of the mean. The standard error of $\pm 0.2 \mathrm{~Sv}$ from Meinen et al. (2010) is too small to be visible. Black triangles on the upper axis indicate the along-stream distances of important geographic locations and sustained transport measurement sites: Florida Cable (FC), Charleston Bump (CB), The Point at Cape Hatteras (CH), PEGASUS line near $73^{\circ} \mathrm{W}$, Oleander line, and Line W. The dashed vertical lines distinguish the three different dynamical regions with boundaries as defined in the text: FS, SAB, MAB (from left to right).

scale estimates purely based on observations are lacking since there are no continuous subsurface measurements with high enough spatial resolution. By applying the sliding window, we obtain upper- and lower-bound estimates of volume transport as a function of along-stream distance (lines in Fig. 10). The standard errors of the weighted means (shading in Fig. 10) are obtained by bootstrapping following Gatz and Smith (1995) and give an indication of how sensitive the time means are to any one transect. The bootstrapped errors are generally less than $5 \mathrm{~Sv}$.

Glider-based volume transport estimates at key locations (Table 1) agree well with independent estimates at those locations. The upper- and lower-bound estimates of $32.9 \pm 1.2 \mathrm{~Sv}$ and $32.3 \pm 1.1 \mathrm{~Sv}$, respectively, in the Florida Strait agree to within error bars with estimates from the Western Boundary Time Series; Meinen et al. (2010) estimated a long-term-mean transport of $32.1 \pm$ $0.2 \mathrm{~Sv}$ from motionally induced voltage differences in a submarine cable across the Florida Strait referenced to repeat ship-based observations (FC in Figs. 1 and 10). Our estimates for the Florida Strait include some transport contribution from the Antilles Current north of the Bahamas, which explains the slightly higher transport values compared to Meinen et al. (2010). Leaman et al. (1989) estimated a Gulf Stream transport of $86.8 \mathrm{~Sv}$ 
TABLE 1. Volume transport by water class at selected locations: Florida Cable (FC), Charleston Bump (CB), The Point at Cape Hatteras $(\mathrm{CH})$, PEGASUS line near $73^{\circ} \mathrm{W}$, Oleander line, and Line W. The total corresponds to the lines in Fig. 10. For each location and water class (see classifications in Fig. 13), the upper row shows the absolute transport (Sv) and the fraction of the total transport (\%) for the upper bound. The lower row (italic) corresponds to the lower- bound. The individual water class transports do not exactly sum up to the total because a few transects with multiprofile gaps in CTD data are excluded from the water class analysis.

\begin{tabular}{|c|c|c|c|c|c|c|c|c|c|c|c|c|}
\hline & \multicolumn{2}{|l|}{$\mathrm{FC}$} & \multicolumn{2}{|l|}{$\mathrm{CB}$} & \multicolumn{2}{|l|}{$\mathrm{CH}$} & \multicolumn{2}{|c|}{ PEGASUS } & \multicolumn{2}{|c|}{ Oleander } & \multicolumn{2}{|c|}{ Line $\mathrm{W}$} \\
\hline Total & $\begin{array}{l}32.9 \pm 1.2 \\
32.3 \pm 1.1\end{array}$ & & $\begin{array}{l}44.0 \pm 1.8 \\
37.7 \pm 1.2\end{array}$ & & $\begin{array}{l}57.3 \pm 1.9 \\
54.5 \pm 1.7\end{array}$ & & $\begin{array}{l}64.1 \pm 2.8 \\
60.5 \pm 2.2\end{array}$ & & $\begin{array}{l}73.8 \pm 2.9 \\
67.1 \pm 2.7\end{array}$ & & $\begin{array}{l}75.6 \pm 4.7 \\
69.9 \pm 4.2\end{array}$ & \\
\hline MABW & $\begin{array}{l}0.1 \pm 0.0 \\
0.1 \pm 0.0\end{array}$ & $\begin{array}{l}0 \% \\
0 \%\end{array}$ & $\begin{array}{l}0.1 \pm 0.0 \\
0.1 \pm 0.0\end{array}$ & $\begin{array}{l}0 \% \\
0 \%\end{array}$ & $\begin{array}{l}0.3 \pm 0.1 \\
0.2 \pm 0.1\end{array}$ & $\begin{array}{l}0 \% \\
0 \%\end{array}$ & $\begin{array}{l}0.6 \pm 0.2 \\
0.5 \pm 0.2\end{array}$ & $\begin{array}{l}1 \% \\
1 \%\end{array}$ & $\begin{array}{l}2.2 \pm 0.4 \\
1.7 \pm 0.3\end{array}$ & $\begin{array}{l}3 \% \\
3 \%\end{array}$ & $\begin{array}{l}2.8 \pm 0.4 \\
2.5 \pm 0.4\end{array}$ & $\begin{array}{l}4 \% \\
4 \%\end{array}$ \\
\hline SW & $\begin{array}{l}5.7 \pm 0.6 \\
5.6 \pm 0.6\end{array}$ & $\begin{array}{l}17 \% \\
17 \%\end{array}$ & $\begin{array}{l}4.9 \pm 0.4 \\
4.4 \pm 0.4\end{array}$ & $\begin{array}{l}11 \% \\
12 \%\end{array}$ & $\begin{array}{l}2.2 \pm 0.5 \\
2.1 \pm 0.5\end{array}$ & $\begin{array}{l}4 \% \\
4 \%\end{array}$ & $\begin{array}{l}2.0 \pm 0.7 \\
2.0 \pm 0.6\end{array}$ & $\begin{array}{l}3 \% \\
3 \%\end{array}$ & $\begin{array}{l}2.0 \pm 0.6 \\
1.8 \pm 0.5\end{array}$ & $\begin{array}{l}3 \% \\
3 \%\end{array}$ & $\begin{array}{l}2.5 \pm 0.6 \\
2.3 \pm 0.6\end{array}$ & $\begin{array}{l}3 \% \\
3 \%\end{array}$ \\
\hline TW & $\begin{array}{l}8.6 \pm 0.7 \\
8.4 \pm 0.7\end{array}$ & $\begin{array}{l}26 \% \\
26 \%\end{array}$ & $\begin{array}{l}12.0 \pm 0.8 \\
10.4 \pm 0.5\end{array}$ & $\begin{array}{l}28 \% \\
28 \%\end{array}$ & $\begin{array}{l}13.9 \pm 0.9 \\
13.4 \pm 0.9\end{array}$ & $\begin{array}{l}25 \% \\
25 \%\end{array}$ & $\begin{array}{l}15.0 \pm 1.1 \\
14.4 \pm 1.1\end{array}$ & $\begin{array}{l}24 \% \\
24 \%\end{array}$ & $\begin{array}{l}14.5 \pm 1.2 \\
13.5 \pm 1.2\end{array}$ & $\begin{array}{l}20 \% \\
20 \%\end{array}$ & $\begin{array}{l}13.1 \pm 1.2 \\
12.4 \pm 1.2\end{array}$ & $\begin{array}{l}17 \% \\
18 \%\end{array}$ \\
\hline EDW & $\begin{array}{l}12.4 \pm 0.6 \\
12.2 \pm 0.6\end{array}$ & $\begin{array}{l}38 \% \\
38 \%\end{array}$ & $\begin{array}{l}18.1 \pm 0.8 \\
15.4 \pm 0.6\end{array}$ & $\begin{array}{l}41 \% \\
41 \%\end{array}$ & $\begin{array}{l}25.1 \pm 1.0 \\
23.7 \pm 0.9\end{array}$ & $\begin{array}{l}44 \% \\
44 \%\end{array}$ & $\begin{array}{l}28.5 \pm 1.4 \\
26.6 \pm 1.2\end{array}$ & $\begin{array}{l}45 \% \\
44 \%\end{array}$ & $\begin{array}{l}34.3 \pm 1.6 \\
30.7 \pm 1.6\end{array}$ & $\begin{array}{l}47 \% \\
47 \%\end{array}$ & $\begin{array}{l}38.4 \pm 3.0 \\
35.2 \pm 2.6\end{array}$ & $\begin{array}{l}51 \% \\
51 \%\end{array}$ \\
\hline IW & $\begin{array}{l}3.0 \pm 0.3 \\
2.9 \pm 0.2\end{array}$ & $\begin{array}{l}9 \% \\
9 \%\end{array}$ & $\begin{array}{l}4.7 \pm 0.3 \\
3.9 \pm 0.2\end{array}$ & $\begin{array}{l}11 \% \\
10 \%\end{array}$ & $\begin{array}{l}7.1 \pm 0.3 \\
6.7 \pm 0.3\end{array}$ & $\begin{array}{l}13 \% \\
12 \%\end{array}$ & $\begin{array}{l}8.4 \pm 0.5 \\
7.8 \pm 0.4\end{array}$ & $\begin{array}{l}13 \% \\
13 \%\end{array}$ & $\begin{array}{r}10.2 \pm 0.5 \\
9.2 \pm 0.5\end{array}$ & $\begin{array}{l}14 \% \\
14 \%\end{array}$ & $\begin{array}{r}10.4 \pm 0.8 \\
9.6 \pm 0.7\end{array}$ & $\begin{array}{l}14 \% \\
14 \%\end{array}$ \\
\hline uLSW & $\begin{array}{l}0.0 \pm 0.0 \\
0.0 \pm 0.0\end{array}$ & $\begin{array}{l}0 \% \\
0 \%\end{array}$ & $\begin{array}{l}1.0 \pm 0.2 \\
0.7 \pm 0.1\end{array}$ & $\begin{array}{l}2 \% \\
2 \%\end{array}$ & $\begin{array}{l}6.9 \pm 0.5 \\
6.6 \pm 0.5\end{array}$ & $\begin{array}{l}12 \% \\
12 \%\end{array}$ & $\begin{array}{l}8.1 \pm 0.7 \\
7.8 \pm 0.6\end{array}$ & $\begin{array}{l}13 \% \\
13 \%\end{array}$ & $\begin{array}{l}9.1 \pm 0.9 \\
8.4 \pm 0.9\end{array}$ & $\begin{array}{l}12 \% \\
13 \%\end{array}$ & $\begin{array}{l}7.6 \pm 1.1 \\
7.2 \pm 1.1\end{array}$ & $\begin{array}{l}10 \% \\
10 \%\end{array}$ \\
\hline AAIW & $\begin{array}{l}2.9 \pm 0.3 \\
2.8 \pm 0.3\end{array}$ & $\begin{array}{l}9 \% \\
9 \%\end{array}$ & $\begin{array}{l}2.9 \pm 0.3 \\
2.5 \pm 0.2\end{array}$ & $\begin{array}{l}7 \% \\
7 \%\end{array}$ & $\begin{array}{l}1.2 \pm 0.2 \\
1.2 \pm 0.2\end{array}$ & $\begin{array}{l}2 \% \\
2 \%\end{array}$ & $\begin{array}{l}1.0 \pm 0.2 \\
1.0 \pm 0.2\end{array}$ & $\begin{array}{l}2 \% \\
2 \%\end{array}$ & $\begin{array}{l}0.6 \pm 0.1 \\
0.6 \pm 0.1\end{array}$ & $\begin{array}{l}1 \% \\
1 \%\end{array}$ & $\begin{array}{l}0.5 \pm 0.2 \\
0.5 \pm 0.2\end{array}$ & $\begin{array}{l}1 \% \\
1 \%\end{array}$ \\
\hline
\end{tabular}

through the PEGASUS line near $73^{\circ} \mathrm{W}$ (maroon line in Fig. 1). Glider-based estimates of volume transport in the upper $1000 \mathrm{~m}$ at the same along-stream distance (about $1500 \mathrm{~km}$ ) capture $70 \%-74 \%$ of the transport measured over the upper $2000 \mathrm{~m}$ by Leaman et al. (1989). Andres et al. (2020) used shipboard ADCP data to estimate Gulf Stream transports of $60.6 \mathrm{~Sv}$ in the upper $600 \mathrm{~m}$ along the Oleander line, which is $82 \%-90 \%$ of our estimate of transport for the upper $1000 \mathrm{~m}$ (Table 1). Andres et al. (2020, their Table A1) estimated an upper-1000-m transport of $69.3 \pm 5.5 \mathrm{~Sv}$ using only Line $\mathrm{W}$ observations, similar to our upperand lower-bound transport estimates of $75.6 \pm 4.7 \mathrm{~Sv}$ and $69.9 \pm 4.2 \mathrm{~Sv}$, respectively, from the combination of Line $\mathrm{W}$ and glider-based observations. However, Andres et al.'s estimates for individual Line W transects may differ from our estimates, in part because they computed transports in a cross-line coordinate system with a single downstream direction for each transect defined by the maximum near-surface velocity and included some profiles that we exclude based on the orientation of depth-average flow. Andres et al. (2020) also reported independent transport estimates from two moorings that observed the Gulf Stream at Line W between 2010 and 2014. Their mooring-based transport estimate of $78.2 \mathrm{~Sv}$ is slightly higher than our estimate but is based on construction of a time-mean Gulf Stream transect from which transport is computed. Overall, the comparison with independent estimates shows that gliders are well suited to measure transport in western boundary currents.

Volume transport increases relatively steadily between the northern end of the Florida Strait (along-stream distance of about $300 \mathrm{~km}$ ) and Line W (along-stream distance of about $2000 \mathrm{~km}$ ). Assuming linear growth and averaging the upper- and lower-bound slopes, transport in the upper kilometer increases by about $2.4 \mathrm{~Sv}$ every $100 \mathrm{~km}$ between those two locations. For comparison, Knauss (1969) estimated that full-depth transport increases at a rate of " $7 \%$ over $100 \mathrm{~km}$ over a distance of $2000 \mathrm{~km}$ downstream of the Florida Straits."

Differences between the upper- and lower-bound transport estimates are largest offshore of South Carolina (alongstream distance of about $750 \mathrm{~km}$ ), a region that is known for curvature and meanders caused by instabilities in the lee of the Charleston Bump (Gula et al. 2015; Zeng and He 2016). Downstream of Cape Hatteras $(>1366 \mathrm{~km})$, the errors on mean transports grow due to a combination of reduced sampling and high Gulf Stream variability. Nevertheless, it appears that differences between upperand lower-bound transports are elevated in this area where the lack of a stabilizing topographic slope allows for the formation of large meanders and eddies.

Following the procedure described in section $3 \mathrm{a}(2)$ without integrating in depth, we estimate the vertical transport profiles for individual transects in both depth and density coordinates. To examine the Gulf Stream structure and transport in the different dynamical regions, 

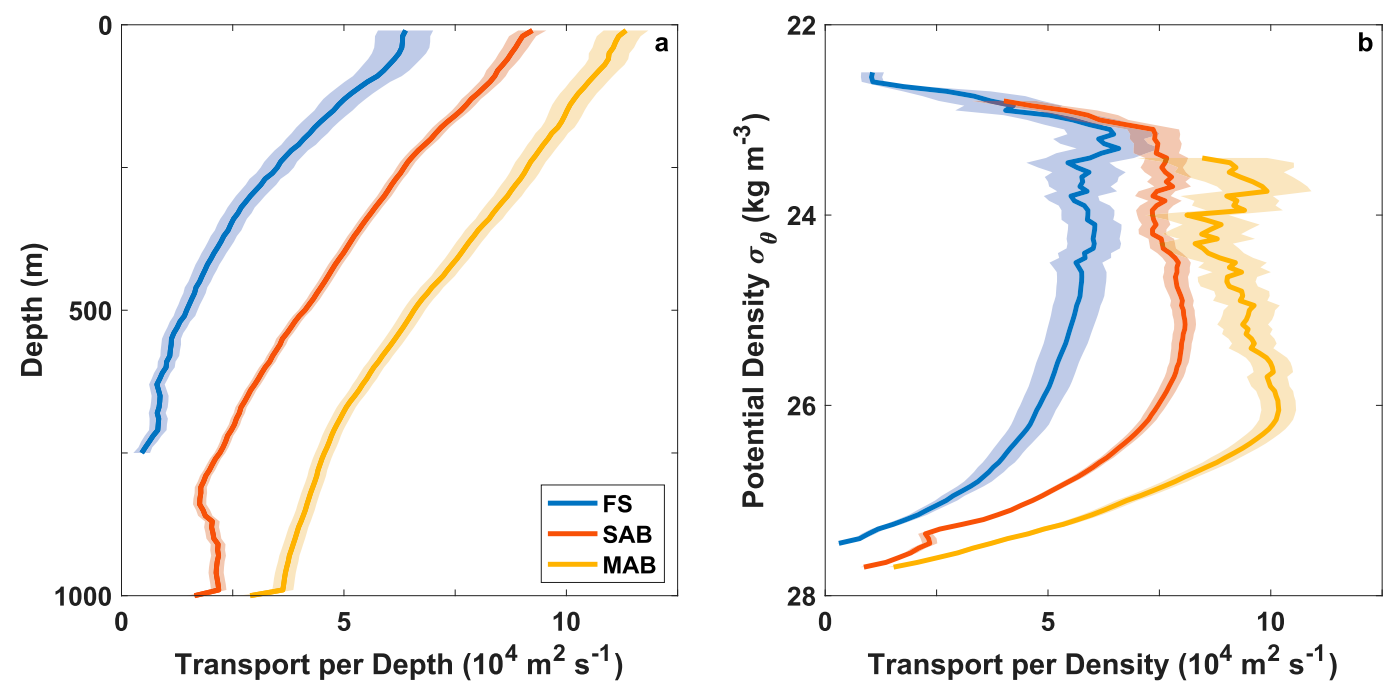

FIG. 11. Vertical structure of volume transport in the FS, MAB, and SAB as a function of (a) depth and (b) potential density $\sigma_{\theta}$. The shading indicates the respective standard error of the mean.

we compute the mean of transport profiles within the FS, $\mathrm{SAB}$, and $\mathrm{MAB}$ regions (Fig. 11). The transport in the upper $1000 \mathrm{~m}$ increases barotropically (i.e., uniformly throughout the water column) over the three different regions (Fig. 11a); transport is highest at the surface and decreases relatively linearly with depth. Near-surface waters become denser as the Gulf Stream flows northward and cools, so most of the transport occurs in denser water classes in the MAB (Fig. 11b). Our observations agree with Hogg (1992), who also observed a downstream barotropic transport increase and nearly constant baroclinic transport in direct velocity observations downstream of Cape Hatteras.

The along-stream increase in Gulf Stream transport must be due to a combination of deepening, acceleration, and/or broadening of the Gulf Stream. Many observational campaigns have shown that the Gulf Stream indeed reaches deeper as the seafloor deepens downstream of Cape Hatteras; it extends to the seafloor in waters greater than $4000 \mathrm{~m}$ deep (e.g., Hall and Bryden 1985; Johns et al. 1995; Andres et al. 2020). We capture the depth-related increase in transport as the Gulf Stream moves from the Florida Strait, over the Blake Plateau, and into deeper water at Cape Hatteras (Fig. 11), but since the gliders only sample the upper kilometer of the ocean, our analysis cannot fully address increases in transport due to the Gulf Stream reaching deeper than $1000 \mathrm{~m}$. To address whether Gulf Stream speeds increase in the downstream direction, we compute a transport-weighted velocity $\left(\langle\mathbf{v}\rangle=\sum T_{i j} \mathbf{v}_{i j} / \sum T_{i j}\right)$ using the individual upper- and lower-bound transport measurements $T_{i j}$ as weights for all transects with Doppler current profiler data. We apply the Gaussian weighted mean and bootstrapping described in section $3 \mathrm{a}(3)$ and then take the magnitude of the result as the transportweighted speed (Fig. 12a). The time-average Gulf Stream speed is relatively constant along the U.S. East Coast, suggesting that the along-stream transport increase above $1000 \mathrm{~m}$ is due to an along-stream increase in Gulf Stream cross-sectional area. We note, however,

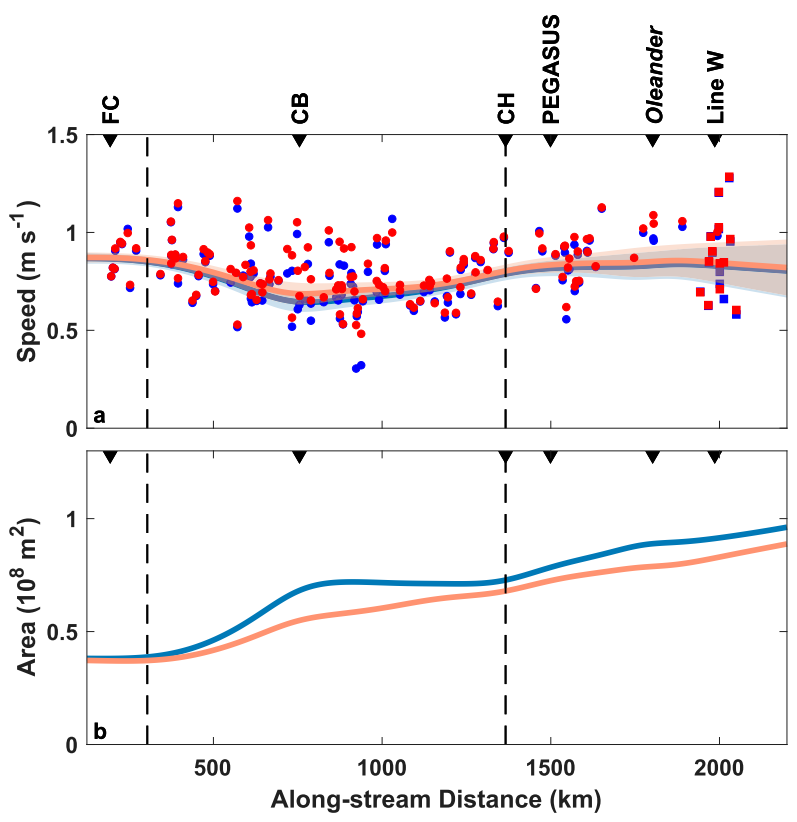

FIG. 12. (a) Transport-weighted speed and (b) inferred Gulf Stream area above $1000 \mathrm{~m}$ as functions of along-stream distance. Colors, lines, symbols, vertical dashed lines, and location indicators as in Fig. 10. The shading is the standard error of the weighted mean velocity and assumes that all of the error in velocity is due to an error in speed and not direction. 


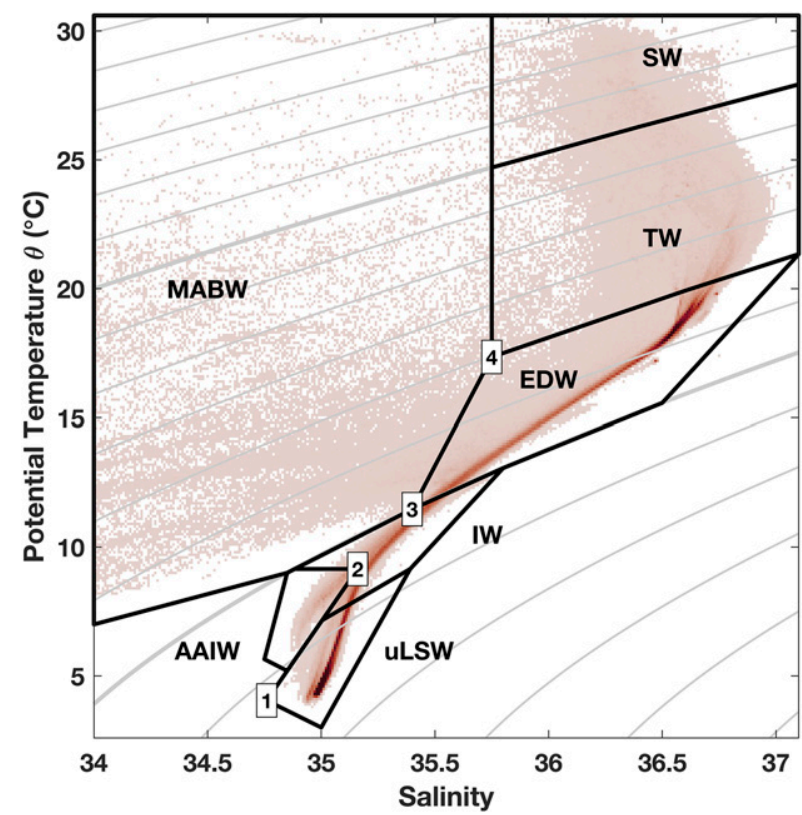

FIG. 13. Joint probability density function for potential temperature $\theta$ and salinity using all available glider observations. Gray contours are isopycnals with a contour interval of $0.5 \mathrm{~kg} \mathrm{~m}^{-3}$ and the 24.0 and $27.0 \mathrm{~kg} \mathrm{~m}^{-3}$ isopycnals bold. Black regions delineate the following water classes: Gulf Stream surface water (SW), Gulf Stream thermocline waters (TW), Eighteen Degree Water and related subthermocline waters (EDW), upper Labrador Sea Water (uLSW), Antarctic Intermediate Water (AAIW), other intermediate waters (IW), and fresher waters that have been influenced by the Middle Atlantic Bight shelf waters (MABW). The MABW region extends to much lower salinities than shown to capture the freshest waters encountered. Coordinates of the numbered vertices used to delineate water classes are given in Table 2. Water class boundaries not including numbered vertices either follow isolines of potentia density $\sigma_{\theta}$, potential temperature $\theta$, or salinity, or they are arbitrarily positioned outside of the range of observed water properties.

that Andres et al. (2020) found a significant change in Gulf Stream speed between the Oleander line and Line W, which are separated by too short of a distance for such a difference to be resolved by our analysis. Unfortunately, directly estimating Gulf Stream cross-sectional area from the available observations is not possible since transects are oriented obliquely and the Gulf Stream curves and evolves along its path. However, we can estimate the Gulf Stream area by dividing our time-average transport estimate by the time-average speed estimate (Fig. 12b). This calculation provides a rough estimate of the alongstream increase in Gulf Stream cross-stream area; addressing these changes more accurately requires a numerical model that can be sampled orthogonal to the local flow. Nevertheless, it is clear that most of the alongstream transport increase in the Gulf Stream stems from broadening and deepening of the current, rather than from increasing current speeds.
TABLE 2. Potential temperature $\theta$, salinity $S$, and potential density $\sigma_{\theta}$ of labeled water class box vertices in Fig. 13.

\begin{tabular}{crcc}
\hline \hline Vertex No. & $\theta\left({ }^{\circ} \mathrm{C}\right)$ & $S$ & $\sigma_{\theta}\left(\mathrm{kg} \mathrm{m}^{-3}\right)$ \\
\hline 1 & 4.05 & 34.76 & 27.6 \\
2 & 9.15 & 35.16 & 27.2 \\
3 & 11.47 & 35.40 & 27.0 \\
4 & 17.35 & 35.75 & 26.0 \\
\hline
\end{tabular}

\section{b. Water class contributions}

With concurrent measurements of water properties and currents distributed along the Gulf Stream's path, the combined glider and Line $\mathrm{W}$ observations are uniquely suited to examine the characteristics of waters transported in the Gulf Stream, where they are entrained, and how they contribute to the Gulf Stream's time-mean increase in along-stream transport. We divide the total volume transport for each transect (Fig. 10) into multiple water classes based on potential temperature $\theta$, salinity, and potential density $\sigma_{\theta}$ (Fig. 13, Table 2). These water classes are more broadly defined than typical for specific "water masses" so as to include all observed water properties in a manageable number of categories. Water classes are chosen to allow direct comparison between our results and those of Szuts and Meinen (2017) in the Florida Strait, but with additional divisions in $\theta-S$ space to account for the larger region and wider range of water properties in our observations. We distinguish the following water classes:

- high-salinity, near-surface Gulf Stream waters (SW; Szuts and Meinen 2017);

- warm, salty Gulf Stream thermocline waters (TW) including Salinity Maximum Water (Toole et al. 2011; Qu et al. 2013);

- Eighteen Degree Water (Worthington 1959; Talley and McCartney 1982) and related waters below the thermocline (EDW);

- fresher, near-surface waters from the Middle Atlantic Bight shelf and the Slope Sea (MABW), including the Ford Water (Ford et al. 1952);

- upper Labrador Sea Water (uLSW);

- Antarctic Intermediate Water (AAIW);

- and other intermediate waters (IW).

Surface waters (SW) are lighter than $24 \mathrm{~kg} \mathrm{~m}^{-3}$ and middepth waters (TW and EDW) are between 24 and $27 \mathrm{~kg} \mathrm{~m}^{-3}$ (Szuts and Meinen called these intermediate waters). We subdivide the middepth waters into TW and EDW based on the $26 \mathrm{~kg} \mathrm{~m}^{-3}$ isopycnal. MABW was not encountered in Szuts and Meinen's observations in the Florida Strait. We define MABW to be lighter than $27 \mathrm{~kg} \mathrm{~m}^{-3}$ and fresher than 35.75 except at potential densities greater than $26 \mathrm{~kg} \mathrm{~m}^{-3}$, where we require it to 


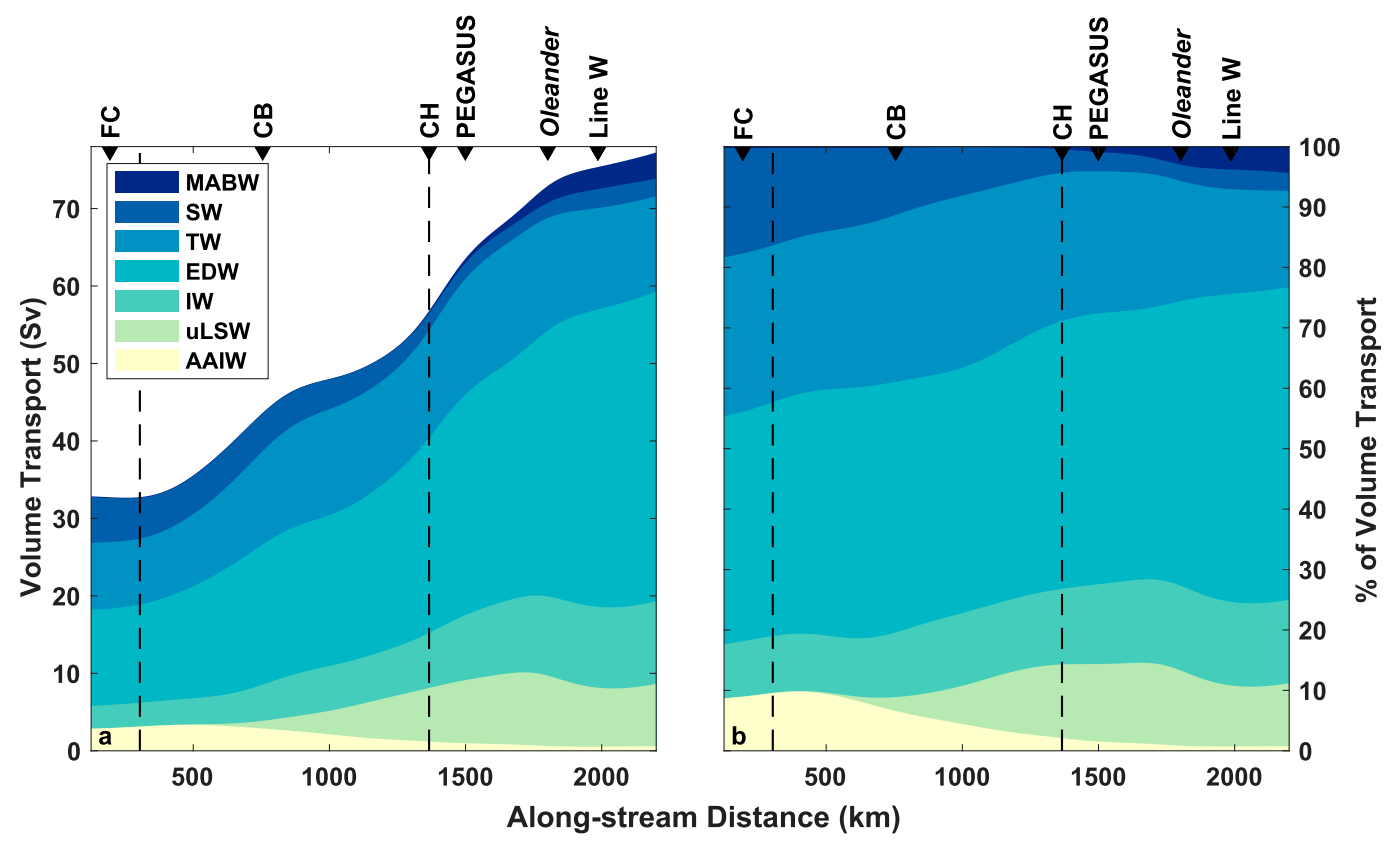

FIG. 14. Along-stream evolution of Gulf Stream volume transport by water class (as defined in Fig. 13) using the upper-bound transport estimates. (a) Stacked area plot of absolute volume transport for each water class. (b) Volume transport by water class as a fraction of the total transport. Vertical dashed lines and triangular tick marks on the upper axes are as in Fig. 10.

be progressively fresher with increasing density in order to distinguish it from EDW (Fig. 13). Our definition of MABW includes a wide range of properties. At potential densities greater than $27.2 \mathrm{~kg} \mathrm{~m}^{-3}$, two distinct modes are apparent in the $\theta-S$ distribution (Fig. 13), motivating our distinction between saltier uLSW and fresher AAIW. Following Pickart and Smethie (1993), we take uLSW to be denser than $27.4 \mathrm{~kg} \mathrm{~m}^{-3}$. Based on where the two modes of the $\theta-S$ distribution merge (vertex 2 in Fig. 13), we define AAIW to be colder than $9.15^{\circ} \mathrm{C}$. Similar to the distinction between MABW and EDW, we also use a linear function in $\theta-S$ space to separate uLSW and AAIW based on the appearance of the two distinct modes. Details of the linear functions that are used to delineate water classes can be found in Table 2, which contains coordinates of the numbered vertices in Fig. 13. Remaining waters denser than $27 \mathrm{~kg} \mathrm{~m}^{-3}$ are then simply categorized as IW. Szuts and Meinen (2017) classified all waters denser than $27 \mathrm{~kg} \mathrm{~m}^{-3}$ as AAIW; uLSW was not encountered in their observations in the Florida Strait, and they did not distinguish between IW and AAIW based on temperature.

For each cross-Gulf Stream transect, every transport element $T_{i j}$ is assigned to a water class based on measured water properties. We then compute the upper and lower- bounds of time-mean volume transport as a function of along-stream distance separately for each water class, following the method described in section $3 a$. The results (Fig. 14a) elucidate the spatially dependent contributions of each water class to Gulf Stream volume transport. We also compute the fractional contribution of each water class to total transport (Fig. 14b). Since the upper- and lower-bound volume transport estimates by water class are similar, we only show the upper-bound estimates in Fig. 14. Table 1 provides both upper- and lower-bound transport estimates at selected locations. The sum of transports in distinct water classes in Fig. 14a approximates the upper-bound total transport (blue line in Fig. 10), but the two estimates do not agree exactly because five transects with multiprofile gaps in the CTD data had to be excluded from the water class analysis (see Table 1).

Most of the along-stream increase in Gulf Stream volume transport is due to entrainment of EDW and, to a slightly lesser extent, uLSW and IW (Fig. 14, Table 1). Transport of EDW increases by about $25 \mathrm{~Sv}$ between the Florida Strait and Line W. Entrainment of uLSW becomes more prominent near the Charleston Bump (along-stream distance of about $750 \mathrm{~km}$ ). At Line W, uLSW contributes approximately $7-8 \mathrm{~Sv}$ or about $10 \%$ of the total transport above $1000 \mathrm{~m}$. While the fraction of EDW transported in the Gulf Stream increases, the relative transport contribution of uLSW also becomes more important downstream (Fig. 14b). It is interesting to note that the glider observations allow us to identify poleward-flowing 
uLSW in the Gulf Stream well south of Cape Hatteras, suggesting a process driving entrainment from the DWBC into the Gulf Stream south of Cape Hatteras. The transport of waters classified as IW increases by about a factor of 3 downstream in concert with increases in EDW and uLSW transport, as would be expected for these waters that lie on a mixing line between adjacent water classes.

As anticipated, MABW is only encountered north of Cape Hatteras ( $>1366 \mathrm{~km}$, Fig. 14). It makes up only a small fraction of total Gulf Stream transport (3Sv, $4 \%$ at Line $\mathrm{W}$ ), but this is notably more than the typical $<1 \mathrm{~Sv}$ of transport encountered on the MAB shelf (Linder and Gawarkiewicz 1998; Lentz 2008; Todd 2020) due to mixing with Slope Sea and Gulf Stream waters during entrainment.

The absolute and fractional transport of AAIW within the Gulf Stream decreases downstream (Fig. 14). The AAIW signature in $\theta-S$ space is eroded as the Gulf Stream flows northward from the Florida Strait, in part due to near-bottom mixing over the Blake Plateau (Todd 2017), but can be traced at least as far as Line W. Previous studies have identified AAIW at different locations in the Gulf Stream using its unique nutrient, oxygen, and silica signatures [e.g., Atkinson (1983) at $31^{\circ} \mathrm{N}$ and Tsuchiya $(1989)$ at $\left.60^{\circ} \mathrm{N}\right]$. Combined with our observations, these studies suggest that AAIW is likely carried far downstream in the Gulf Stream but modified along the way.

The transport of waters classified as SW also decreases downstream (Fig. 14). The combination of heat loss to the atmosphere, which leads to cooling and reclassification as TW, and mixing with entrained MABW likely accounts for this decrease despite the increase in transport in the downstream direction at all depths (Fig. 11).

Our transport estimates by water class agree well with prior results from Szuts and Meinen (2017) in the Florida Strait. They estimated that $14 \%$ of the Florida Current transport comes from AAIW, similar to our estimate of $18 \%$ for the combination of AAIW and IW. Szuts and Meinen observed a larger fraction of surface waters $(27 \%$ vs our $17 \%)$. Consequently, the fraction of waters with properties last set in the North Atlantic (a combination of EDW and TW) is slightly lower in Szuts and Meinen than for the glider-based estimates presented here $(55 \%$ vs our $64 \%)$.

\section{Summary and conclusions}

Using a combination of glider-based cross-Gulf Stream transects and shipboard observations along Line W, this analysis characterizes the time-mean along-stream evolution of Gulf Stream volume transport in the upper kilometer of the ocean. Using two different definitions of Gulf Stream transport, we provide both an upper and a lower- bound for Gulf Stream transport in the different dynamical regimes along the U.S. East Coast (Fig. 10). Our analysis confirms the well-known alongstream increase in Gulf Stream volume transport, filling in the large spatial gaps between existing estimates of Gulf Stream transport. The transport estimates reported here are averages of the transport through individual transects; they are not directly comparable to estimates of transport through streamwise mean sections because of the variable width of the Gulf Stream. The concurrent hydrographic and velocity measurements used here additionally allow us to examine how waters of various properties contribute to the Gulf Stream's evolving flow along the U.S. East Coast. Subthermocline waters are the leading contributors to the Gulf Stream's added transport as it flows from the Florida Strait into the open North Atlantic (Fig. 14).

Recently detected changes in the behavior of the Gulf Stream (Andres 2016) and other western boundary currents (e.g., Beal and Elipot 2016; Yang et al. 2016), as well as the projected shifts in meridional overturning as a consequence of anthropogenic climate change (e.g., IPCC 2013, and references therein) highlight the importance of understanding the structure, dynamics, and variability of western boundary currents under climatological conditions for improving forecasts. Autonomous underwater gliders enable long-duration, high-resolution monitoring of the upper kilometer of western boundary currents (Davis et al. 2012; Rainville et al. 2013; Rudnick et al. 2013; Schaeffer and Roughan 2015; Schönau et al. 2015; Todd et al. 2016; Krug et al. 2017; Todd 2017). This study presents a first detailed look at the evolution of Gulf Stream transport along the U.S. East Coast, emphasizing the potential of underwater gliders to continuously monitor western boundary currents as the Global Ocean Observing System expands its coverage of ocean boundaries (Todd et al. 2019).

Details of the modification of water masses transported in the Gulf Stream remain to be investigated, particularly in the areas around the Charleston Bump, where nearbottom mixing is enhanced (Todd 2017), and near Cape Hatteras, where the Gulf Stream encounters the deep western boundary current (e.g., Andres et al. 2018). Frequent occurrences of upper Labrador Sea Water south of Cape Hatteras in the glider observations leave many open questions about the pathways of this intermediate water mass and their persistence. Realistic numerical simulations that capture observed Gulf Stream properties and provide water mass distributions below 1000-m depth will be beneficial to such future analyses.

Acknowledgments. Many people were critical to the success of the Spray glider missions, including Patrick 
Deane, Larry George, Raymond Graham, Ben Hodges, and Breck Owens at WHOI and Jeff Sherman, Dan Rudnick, Ben Reineman, and Evan Randall-Goodwin of the Instrument Development Group at the Scripps Institution of Oceanography. The Physical Oceanography Division at NOAA's Atlantic Oceanographic and Meteorological Laboratory (AOML) and the University of Miami's Rosenstiel School of Marine and Atmospheric Science (RSMAS) provided laboratory space for glider preparation. The East Carolina University Coastal Studies Institute and North Carolina State University's Center for Marine Sciences and Technology (CMAST) provided support for glider recoveries. We thank Magdalena Andres, John Bane, Glenn Flierl, and John Toole for valuable discussions about Gulf Stream transport and for their thoughtful suggestions and comments on the manuscript. We gratefully acknowledge funding from the Office of Naval Research (N000141713040), the National Science Foundation (OCE-0220769, OCE-1633911, OCE-1923362), NOAA's Global Ocean Monitoring and Observing Program (NA14OAR4320158, NA19OAR4320074), WHOI's Oceans and Climate Change Institute, Eastman Chemical Company, and the W. Van Alan Clark, Jr. Chair for Excellence in Oceanography at WHOI (awarded to Breck Owens).

Data Availability Statement. Spray glider observations in the Gulf Stream are available from http:// spraydata.ucsd.edu and should be cited using the following DOI:10.21238/S8SPRAY2675 (Todd and Owens 2016). Line W shipboard hydrographic data are accessible from the Line W project website (https://scienceweb.whoi.edu/ linew/index.php). The daily delayed-time (SEALEVEL GLO_PHY_L4_REP_OBSERVATIONS_008_047) and near-real-time (SEALEVEL_GLO_PHY_L4_ NRT_OBSERVATIONS_008_046) absolute dynamic topography products used in this study are provided by the EU Copernicus Marine Environmental Monitoring Service. Color maps are from Thyng et al. (2016).

\section{REFERENCES}

Andres, M., 2016: On the recent destabilization of the Gulf Stream path downstream of Cape Hatteras. Geophys. Res. Lett., 43, 9836-9842, https://doi.org/10.1002/2016GL069966.

_- M. Muglia, F. Bahr, and J. Bane, 2018: Continuous flow of upper Labrador Sea Water around Cape Hatteras. Sci. Rep., 8, 4494, https://doi.org/10.1038/s41598-018-22758-z.

— K. A. Donohue, and J. M. Toole, 2020: The Gulf Stream's path and time-averaged velocity structure and transport at $68.5^{\circ} \mathrm{W}$ and $70.3^{\circ} \mathrm{W}$. Deep-Sea Res. I, 156, 103179, https:// doi.org/10.1016/J.DSR.2019.103179.

Atkinson, L. P., 1983: Distribution of Antarctic intermediate water over the Blake Plateau. J. Geophys. Res., 88, 4699-4704, https://doi.org/10.1029/JC088iC08p04699.
Baringer, M. O., and J. C. Larsen, 2001: Sixteen years of Florida Current transport at $27^{\circ}$ N. Geophys. Res. Lett., 28, 3179-3182, https://doi.org/10.1029/2001GL013246.

Beal, L. M., and S. Elipot, 2016: Broadening not strengthening of the Agulhas Current since the early 1990s. Nature, 540, 570573, https://doi.org/10.1038/nature19853.

Bower, A. S., and H. D. Hunt, 2000: Lagrangian observations of the deep western boundary current in the North Atlantic Ocean. Part I: Large-scale pathways and spreading rates. J. Phys. Oceanogr., 30, 764-783, https://doi.org/10.1175/15200485(2000)030<0764:LOOTDW > 2.0.CO;2.

Bretherton, F. P., R. E. Davis, and C. B. Fandry, 1976: A technique for objective analysis and design of oceanographic experiments applied to MODE-73. Deep-Sea Res. Oceanogr. Abstr., 23, 559-582, https://doi.org/10.1016/0011-7471(76)90001-2.

Cornillon, P., 1986: The effect of the New England seamounts on Gulf Stream meandering as observed from satellite IR imagery. J. Phys. Oceanogr., 16, 386-389, https://doi.org/10.1175/ 1520-0485(1986)016<0386:TEOTNE>2.0.CO;2.

Csanady, G. T., and P. Hamilton, 1988: Circulation of slopewater. Cont. Shelf Res., 8, 565-624, https://doi.org/10.1016/02784343(88)90068-4.

Cunningham, S. A., and Coauthors, 2007: Temporal variability of the Atlantic meridional overturning circulation at $26.5^{\circ} \mathrm{N}$. Science, 317, 935-938, https://doi.org/10.1126/science.1141304.

Davis, R. E., W. S. Kessler, and J. T. Sherman, 2012: Gliders measure western boundary current transport from the South Pacific to the equator. J. Phys. Oceanogr., 42, 2001-2013, https://doi.org/10.1175/JPO-D-12-022.1.

Flagg, C. N., M. Dunn, D.-P. Wang, H. T. Rossby, and R. L. Benway, 2006: A study of the currents of the outer shelf and upper slope from a decade of shipboard ADCP observations in the Middle Atlantic Bight. J. Geophys. Res., 111, C06003, https://doi.org/10.1029/2005JC003116.

Ford, W. L., J. R. Longard, and R. E. Banks, 1952: On the nature, occurrence and origin of cold low salinity water along the edge of the Gulf Stream. J. Mar. Res., 11, 281-293.

Fuglister, F. C., and A. D. Voorhis, 1965: A new method of tracking the Gulf Stream. Limnol. Oceanogr., 10 (Suppl.), R115-R124, https://doi.org/10.4319/lo.1965.10.suppl2.r115.

Gatz, D. F., and L. Smith, 1995: The standard error of a weighted mean concentration-I. Bootstrapping vs other methods. Atmos. Environ., 29, 1185-1193, https://doi.org/10.1016/1352-2310(94) 00210-C.

Glenn, S. M., and C. C. Ebbesmeyer, 1994: Observations of Gulf Stream frontal eddies in the vicinity of Cape Hatteras. J. Geophys. Res., 99, 5047-5055, https://doi.org/10.1029/93JC02787.

Gula, J., M. J. Molemaker, and J. C. McWilliams, 2015: Gulf Stream dynamics along the southeastern U.S. seaboard. J. Phys. Oceanogr., 45, 690-715, https://doi.org/10.1175/JPOD-14-0154.1.

Halkin, D., and T. Rossby, 1985: The structure and transport of the Gulf Stream at $73^{\circ}$ W. J. Phys. Oceanogr., 15, 1439-1452, https:// doi.org/10.1175/1520-0485(1985)015<1439:TSATOT>2.0.CO;2.

Hall, M. M., and H. L. Bryden, 1985: Profiling the Gulf Stream with a current meter mooring. Geophys. Res. Lett., 12, 203 206, https://doi.org/10.1029/GL012i004p00203.

Hansen, D. V., 1970: Gulf Stream meanders between Cape Hatteras and the Grand Banks. Deep-Sea Res. Oceanogr. Abstr., 17, 495511, https://doi.org/10.1016/0011-7471(70)90064-1.

Hogg, N. G., 1992: On the transport of the Gulf Stream between Cape Hatteras and the Grand Banks. Deep-Sea Res., 39A, 1231-1246, https://doi.org/10.1016/0198-0149(92)90066-3. 
— R. R. Pickart, R. M. Hendry, and W. J. Smethie Jr., 1986: The northern recirculation gyre of the Gulf Stream. Deep-Sea Res., 33A, 1139-1165, https://doi.org/10.1016/0198-0149(86)90017-8.

IPCC, 2013: Climate Change 2013: The Physical Science Basis. Cambridge University Press, 1535 pp., https://doi.org/10.1017/ CBO9781107415324.

Iselin, C. O'D., 1940: Preliminary report on the long-period variations in the transport of the Gulf Stream system. Pap. Phys. Oceanogr. Meteor., 8, 1-40, https://doi.org/10.1575/1912/1048.

Johns, E., D. R. Watts, and H. T. Rossby, 1989: A test of geostrophy in the Gulf Stream. J. Geophys. Res., 94, 3211-3222, https:// doi.org/10.1029/JC094iC03p03211.

Johns, W. E., T. J. Shay, J. M. Bane, and D. R. Watts, 1995: Gulf Stream structure, transport, and recirculation near $68^{\circ} \mathrm{W}$. J. Geophys. Res., 100, 817-838, https://doi.org/10.1029/94JC02497.

Joyce, T. M., C. Deser, and M. A. Spall, 2000: The relation between decadal variability of subtropical mode water and the North Atlantic Oscillation. J. Climate, 13, 2550-2569, https://doi.org/ 10.1175/1520-0442(2000)013<2550:TRBDVO > 2.0.CO; 2 .

Knauss, J. A., 1969: A note on the transport of the Gulf Stream. Deep-Sea Res., 16 (Suppl.), 117-123.

Krug, M., S. Swart, and J. Gula, 2017: Submesoscale cyclones in the Agulhas current. Geophys. Res. Lett., 44, 346-354, https:// doi.org/10.1002/2016GL071006.

Kwon, Y.-O., M. A. Alexander, N. A. Bond, C. Frankignoul, H. Nakamura, B. Qiu, and L. A. Thompson, 2010: Role of the Gulf Stream and Kuroshio-Oyashio systems in large-scale atmosphere-ocean interaction: A review. J. Climate, 23, 32493281, https://doi.org/10.1175/2010JCLI3343.1.

Leaman, K. D., E. Johns, and T. Rossby, 1989: The average distribution of volume transport and potential vorticity with temperature at three sections across the Gulf Stream. J. Phys. Oceanogr., 19, 36-51, https://doi.org/10.1175/1520-0485(1989) 019<0036:TADOVT > 2.0.CO;2.

Le Bras, I. A., I. Yashayaev, and J. M. Toole, 2017: Tracking Labrador Sea Water property signals along the Deep Western Boundary Current. J. Geophys. Res. Oceans, 122, 5348-5366, https://doi.org/10.1002/2017JC012921.

Lee, T. N., and L. P. Atkinson, 1983: Low-frequency current and temperature variability from Gulf Stream frontal eddies and atmospheric forcing along the southeast U.S. outer continental shelf. J. Geophys. Res., 88, 4541-4567, https://doi.org/ 10.1029/JC088iC08p04541.

Lentz, S. J., 2008: Observations and a model of the mean circulation over the Middle Atlantic Bight continental shelf. J. Phys. Oceanogr., 38, 1203-1221, https://doi.org/10.1175/2007JPO3768.1.

Levine, E. R., D. N. Connors, P. C. Cornillon, and H. T. Rossby, 1986: Gulf Stream kinematics along an isopycnal float trajectory. J. Phys. Oceanogr., 16, 1317-1328, https://doi.org/10.1175/ 1520-0485(1986)016<1317:GSKAAI $>2.0$. CO;2.

Lillibridge, J. L., III, and A. J. Mariano, 2013: A statistical analysis of Gulf Stream variability from $18+$ years of altimetry data. Deep-Sea Res. II, 85, 127-146, https://doi.org/10.1016/ j.dsr2.2012.07.034.

Linder, C. A., and G. Gawarkiewicz, 1998: A climatology of the shelfbreak front in the Middle Atlantic Bight. J. Geophys. Res., 103, 18 405-18 423, https://doi.org/10.1029/98JC01438.

Meinen, C. S., and D. S. Luther, 2016: Structure, transport, and vertical coherence of the Gulf Stream from the Straits of Florida to the Southeast Newfoundland Ridge. Deep-Sea Res. I, 112, 137-154, https://doi.org/10.1016/j.dsr.2016.03.002.

— M. O. Baringer, and R. F. Garcia, 2010: Florida Current transport variability: An analysis of annual and longer-period signals. Deep-Sea Res. I, 57, 835-846, https://doi.org/10.1016/ j.dsr.2010.04.001.

, and Coauthors, 2019: Structure and variability of the Antilles Current at $26.5^{\circ}$ N. J. Geophys. Res. Oceans, 124, 3700-3723, https://doi.org/10.1029/2018JC014836.

Mellor, G. L., and T. Ezer, 1991: A Gulf Stream model and an altimetry assimilation scheme. J. Geophys. Res., 96, 87798795, https://doi.org/10.1029/91JC00383.

Munk, W. H., 1950: On the wind-driven ocean circulation. J. Meteor., 7, 80-93, https://doi.org/10.1175/1520-0469(1950) 007<0080:OTWDOC $>2.0 . \mathrm{CO} ; 2$.

Pickart, R. S., and W. M. Smethie Jr., 1993: How does the deep western boundary current cross the Gulf Stream? J. Phys. Oceanogr., 23, 2602-2616, https://doi.org/10.1175/1520-0485(1993) $023<2602$ :HDTDWB $>2.0$. CO 2 .

Qu, T., S. Gao, and I. Fukumori, 2013: Formation of salinity maximum water and its contribution to the overturning circulation in the North Atlantic as revealed by a global general circulation model. J. Geophys. Res. Oceans, 118, 1982-1994, https://doi.org/10.1002/jgrc.20152.

Rainville, L., C. M. Lee, D. L. Rudnick, and K.-C. Yang, 2013: Propagation of internal tides generated near Luzon Strait: Observations from autonomous gliders. J. Geophys. Res. Oceans, 118, 4125-4138, https://doi.org/10.1002/jgrc.20293.

Richardson, P. L., 1985: Average velocity and transport of the Gulf Stream near 55W. J. Mar. Res., 43, 83-111, https://doi.org/ 10.1357/002224085788437343.

Rossby, T., C. Flagg, and K. Donohue, 2010: On the variability of Gulf Stream transport from seasonal to decadal timescales. J. Mar. Res., 68, 503-522, https://doi.org/10.1357/ 002224010794657128

Rudnick, D. L., and S. T. Cole, 2011: On sampling the ocean using underwater gliders. J. Geophys. Res., 116, C08010, https:// doi.org/10.1029/2010JC006849.

, T. M. S. Johnston, and J. T. Sherman, 2013: High-frequency internal waves near the Luzon Strait observed by underwater gliders. J. Geophys. Res. Oceans, 118, 774-784, https://doi.org/ 10.1002/jgrc.20083.

— R. E. Davis, and J. T. Sherman, 2016: Spray underwater glider operations. J. Atmos. Oceanic Technol., 33,1113-1122, https:// doi.org/10.1175/JTECH-D-15-0252.1.

—, K. D. Zaba, R. E. Todd, and R. E. Davis, 2017: A climatology of the California Current System from a network of underwater gliders. Prog. Oceanogr., 154, 64-106, https://doi.org/ 10.1016/j.pocean.2017.03.002.

, J. T. Sherman, and A. P. Wu, 2018: Depth-average velocity from Spray underwater gliders. J. Atmos. Oceanic Technol., 35, 1665-1673, https://doi.org/10.1175/JTECH-D-17-0200.1.

Sanchez-Franks, A., C. N. Flagg, and T. Rossby, 2014: A comparison of transport and position between the Gulf Stream east of Cape Hatteras and the Florida Current. J. Mar. Res., 72, 291-306, https://doi.org/10.1357/002224014815460641.

Schaeffer, A., and M. Roughan, 2015: Influence of a western boundary current on shelf dynamics and upwelling from repeat glider deployments. Geophys. Res. Lett., 42, 121-128, https://doi.org/10.1002/2014GL062260.

Schmittner, A., and E. D. Galbraith, 2008: Glacial greenhouse-gas fluctuations controlled by ocean circulation changes. Nature, 456, 373-376, https://doi.org/10.1038/nature07531.

Schönau, M. C., D. L. Rudnick, I. Cerovecki, G. Gopalakrishnan, B. D. Cornuelle, J. L. McClean, and B. Qiu, 2015: The Mindanao Current: Mean structure and connectivity. Oceanography, 28, 34 45, https://doi.org/10.5670/oceanog.2015.79. 
Sherman, J., R. E. Davis, W. B. Owens, and J. Valdes, 2001: The autonomous underwater glider "Spray." IEEE J. Oceanic Eng., 26, 437-446, https://doi.org/10.1109/48.972076.

Shoosmith, D. R., M. O. Baringer, and W. E. Johns, 2005: A continuous record of Florida Current temperature transport at $27^{\circ}$ N. Geophys. Res. Lett., 32, L23603, https://doi.org/10.1029/ 2005GL024075.

Spall, M. A., 1996: Dynamics of the Gulf Stream/deep western boundary current crossover. Part I: Entrainment and recirculation. J. Phys. Oceanogr., 26, 2152-2168, https://doi.org/ 10.1175/1520-0485(1996)026<2152:DOTGSW >2.0.CO;2.

Stommel, H., 1948: The westward intensification of wind-driven ocean currents. Eos, Trans. Amer. Geophys. Union, 29, $202-$ 206, https://doi.org/10.1029/TR029i002p00202.

— ocean-I. Stationary planetary flow patterns on a sphere. Deep-Sea Res., 6 (Suppl. C), 140-154, https://doi.org/10.1016/ 0146-6313(59)90065-6.

Sverdrup, H. U., 1947: Wind-driven currents in a baroclinic ocean; with application to the equatorial currents of the eastern Pacific. Proc. Natl. Acad. Sci. USA, 33, 318-326, https:// doi.org/10.1073/pnas.33.11.318.

Szuts, Z. B., and C. S. Meinen, 2017: Florida Current salinity and salinity transport: Mean and decadal changes. Geophys. Res. Lett., 44, 10 495-10 503, https://doi.org/10.1002/2017GL074538.

Talley, L. D., and M. S. McCartney, 1982: Distribution and circulation of Labrador Sea Water. J. Phys. Oceanogr., 12, 1189-1205, https:// doi.org/10.1175/1520-0485(1982)012<1189:DACOLS >2.0.CO;2.

Thyng, K. M., C. A. Greene, R. D. Hetland, H. M. Zimmerle, and S. F. DiMarco, 2016: True colors of oceanography: Guidelines for effective and accurate colormap selection. Oceanography, 29, 9-13, https://doi.org/10.5670/oceanog.2016.66.

Todd, R. E., 2017: High-frequency internal waves and thick bottom mixed layers observed by gliders in the Gulf Stream. Geophys. Res. Lett., 44, 6316-6325, https://doi.org/10.1002/2017GL072580. 2020: Export of Middle Atlantic Bight shelf waters near Cape Hatteras from two years of underwater glider observations. J. Geophys. Res. Oceans, 125, e2019JC016006, https://doi.org/ 10.1029/2019JC016006.

— , and W. B. Owens, 2016: Gliders in the Gulf Stream. Scripps Institution of Oceanography, Instrument Development Group, https://doi.org/10.21238/S8SPRAY2675.

, and L. Locke-Wynn, 2017: Underwater glider observations and the representation of western boundary currents in numerical models. Oceanography, 30, 88-89, https://doi.org/ 10.5670/oceanog.2017.225.

—, D. L. Rudnick, M. R. Mazloff, R. E. Davis, and B. D. Cornuelle, 2011: Poleward flows in the southern California Current System: Glider observations and numerical simulation. J. Geophys. Res., 116, C02026, https://doi.org/10.1029/2010JC006536.
— W. B. Owens, and D. L. Rudnick, 2016: Potential vorticity structure in the North Atlantic western boundary current from underwater glider observations. J. Phys. Oceanogr., 46, 327348, https://doi.org/10.1175/JPO-D-15-0112.1.

- D. L. Rudnick, J. T. Sherman, W. B. Owens, and L. George, 2017: Absolute velocity estimates from autonomous underwater gliders equipped with Doppler current profilers. J. Atmos. Oceanic Technol., 34, 309-333, https://doi.org/10.1175/JTECHD-16-0156.1.

— , T. G. Asher, J. Heiderich, J. M. Bane, and R. A. Luettich, 2018: Transient response of the Gulf Stream to multiple hurricanes in 2017. Geophys. Res. Lett., 45, 10 509-10 519, https:// doi.org/10.1029/2018GL079180.

_ , and Coauthors, 2019: Global perspectives on observing ocean boundary current systems. Front. Mar. Sci., 6, 423, https:// doi.org/10.3389/fmars.2019.00423.

Toole, J. M., R. G. Curry, T. M. Joyce, M. McCartney, and B. Peña-Molino, 2011: Transport of the North Atlantic Deep Western Boundary Current about $39^{\circ} \mathrm{N}, 70^{\circ} \mathrm{W}: 2004$ 2008. Deep-Sea Res. II, 58, 1768-1780, https://doi.org/ 10.1016/J.DSR2.2010.10.058.

_ M. Andres, I. A. Le Bras, T. M. Joyce, and M. S. McCartney, 2017: Moored observations of the Deep Western Boundary Current in the NW Atlantic: 2004-2014. J. Geophys. Res. Oceans, 122, 7488-7505, https://doi.org/10.1002/2017JC012984.

Tsuchiya, M., 1989: Circulation of the Antarctic Intermediate Water in the North Atlantic Ocean. J. Mar. Res., 47, 747-755, https://doi.org/10.1357/002224089785076136.

Watts, D. R., and W. E. Johns, 1982: Gulf Stream meanders: Observations on propagation and growth. J. Geophys. Res., 87, 9467-9476, https://doi.org/10.1029/JC087iC12p09467.

Worthington, L. V., 1959: The $18^{\circ}$ water in the Sargasso Sea. Deep-Sea Res., 5, 297-305, https://doi.org/10.1016/01466313(58)90026-1.

- 1976: On the North Atlantic Circulation. Vol. 6. The Johns Hopkins University Press, 110 pp.

Wunsch, C., 2005: The total meridional heat flux and its oceanic and atmospheric partition. J. Climate, 18, 4374-4380, https:// doi.org/10.1175/JCLI3539.1.

— , and D. Roemmich, 1985: Is the North Atlantic in Sverdrup balance? J. Phys. Oceanogr., 15, 1876-1880, https://doi.org/ 10.1175/1520-0485(1985)015<1876:ITNAIS > 2.0.CO;2.

Yang, H., G. Lohmann, W. Wei, M. Dima, M. Ionita, and J. Liu, 2016: Intensification and poleward shift of subtropical western boundary currents in a warming climate.J. Geophys. Res. Oceans, 121, 4928-4945, https://doi.org/10.1002/2015JC011513.

Zeng, X., and R. He, 2016: Gulf Stream variability and a triggering mechanism of its large meander in the South Atlantic Bight. J. Geophys. Res. Oceans, 121, 8021-8038, https://doi.org/ 10.1002/2016JC012077. 